\title{
Multifaceted approach to resveratrol bioactivity Focus on antioxidant action, cell signaling and safety
}

\author{
Peter Kovacic ${ }^{1, *}$ and Ratnasamy Somanathan ${ }^{2}$
}

'Department of Chemistry; San Diego State University; San Diego, CA USA; ${ }^{2}$ Centro de Graduados e Investigación del Instituto Tecnológico de Tijuana; Tijuana, BC Mexico

Key words: resveratrol, bioactivity, mechanism, antioxidant, metabolism, cell signaling, safety

\begin{abstract}
Abbreviations: RVT, resveratrol; ET, electron transfer; ROS, reactive oxygen species; OS, oxidative stress; AO, antioxidant; CNS, central nervous system; ATP, adenosine triphosphate; GSH, glutathione; NO, nitric oxide; 8-OH-dG, 8-hydroxy-d-guanosine;

$\mathrm{PCB}$, polychlorinated biphenyl; AR, androgen receptor; SOD, superoxide dismutase; AA, amino acid
\end{abstract}

Resveratrol (RVT) is a naturally occurring trihydroxy stilbene that displays a wide spectrum of physiological activity. Its ability to behave therapeutically as a component of red wine has attracted wide attention. The phenol acts as a protective agent involving various body constituents. Most attention has been given to beneficial effects in insults involving cancer, aging, cardiovascular system, inflammation and the central nervous system. One of the principal modes of action appears to be as antioxidant. Other mechanistic pathways entail cell signaling, apoptosis and gene expression. There is an intriguing dichotomy in relation to pro-oxidant property. Also discussed are metabolism, receptor binding, rationale for safety and suggestions for future work. This is the first comprehensive review of RVT based on a broad, unifying mechanism.

\section{Introduction}

Resveratrol 1 (Fig. 1) (RVT) is a naturally occurring stilbene derivative that possesses three phenolic groups, two of which are part of a resorcinol structure. Most work involves the naturally occurring trans isomer. It is present in various dietary sources, including grapes, peanuts, plums and many plants. Much recent attention was paid to the "French paradox" (see below) which provides evidence for the beneficial effects of red wine. Investigations pointed to RVT as the principal therapeutic agent. The literature contains voluminous reports on the wide variety of properties by the phenol. Most attention has been devoted to anticancer, anti-aging, anti-inflammatory, cardioprotection and countering of insults to the central nervous system. Articles document a large number of mechanisms involved in the biological activity. One of the most important is the antioxidant (AO) attribute. Considerable literature correlates the presence of reactive oxygen species (ROS) to oxidative stress (OS) leading to large numbers of adverse effects suffered by body constituents. Hence, it is reasonable to assign a widespread protective role to RVT as

*Correspondence to: Peter Kovacic; Email: pkovacic@sundown.sdsu.edu Submitted: 12/18/09; Revised: 01/06/10; Accepted: 01/07/10

Previously published online:

www.landesbioscience.com/journals/oximed/article/11147 an AO. Other mechanisms in which the drug is involved include cell signaling, apoptosis and gene expression. The dichotomy of the AO RVT also exhibiting pro-oxidant action is addressed and rationalized. Another important aspect is the finding that RVT has been shown to produce no adverse effects, even when consumed in high concentrations. ${ }^{1}$ Hence, it exhibits good protection for use in therapy for various diseases.

Reviews demonstrate the widespread involvement of ROS-OS in cancer and toxicity associated with many illnesses. The preponderance of bioactive substances and their metabolites incorporate ET functionalities, which, we believe, play an important role in physiological responses. The main groups include quinones (or phenolic precursors), metal complexes (or complexors), aromatic nitro compounds (or reduced hydroxylamine and nitroso derivatives) and conjugated imines or iminium species. In vivo redox cycling with oxygen can occur giving rise to OS through generation of ROS, such as hydrogen peroxide, hydroperoxides, alkyl peroxides, and diverse radicals (hydroxyl, alkoxyl, hydroperoxyl), and superoxide. In some cases, ET results in interference with normal electrical effects, e.g., in respiration or neurochemistry. Generally, active entities possessing ET groups display reduction potentials in the physiologically responsive range, i.e., more positive than $-0.5 \mathrm{~V}$ ET, ROS and OS have been increasingly implicated in the mode of action of drugs and toxins (toxicants) e.g., antiinfective agents, ${ }^{2}$ anticancer drugs, ${ }^{3}$ carcinogens, ${ }^{4}$ reproductive toxins, ${ }^{5}$ nephrotoxins, ${ }^{6}$ hepatotoxins, ${ }^{7}$ cardiovascular toxins, ${ }^{8}$ nerve toxins, ${ }^{9}$ mitochondrial toxins,${ }^{10}$ abused drugs,,${ }^{11}$ ototoxins, ${ }^{12}$ pulmonary toxins, ${ }^{13}$ immune system toxins, ${ }^{14}$ and various other categories of drugs and toxins, including human illnesses. ${ }^{15}$

There is a plethora of experimental evidence supporting the OS theoretical framework, including generation of the common ROS, lipid peroxidation, degradation products of oxidation, depletion of AOs, and DNA oxidation and cleavage products, as well as electrochemical data. Of particular relevance in the present case is the prevalent beneficial effect of $\mathrm{AOs},{ }^{16}$ in connection with RVT. This comprehensive, unifying mechanism is in keeping with the frequent observations that many ET substances display a variety of activities, e.g., multiple drug properties, as well as toxic effects. Knowledge of events at the molecular level can result in practical application in medicine. 


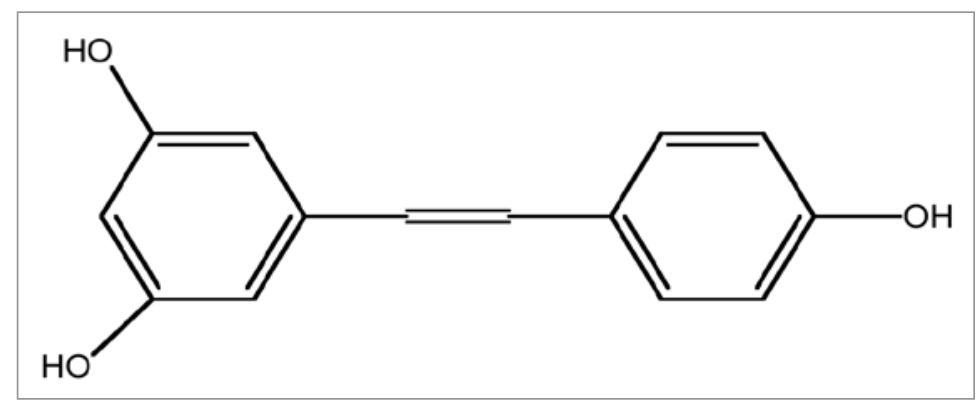

Figure 1. Resveratrol structure. The compound is a stilbene derivative containing three phenolic groups. Hence, it can exert $\mathrm{AO}$ action which evidently plays an important role in the protective effects observed against oxidative insult involving various body constituents. Metabolic studies show major formation of water-soluble conjugates. Many investigations deal with cell signaling pathways in the bioactivity. Particular focus has been devoted to antiaging, anti-cancer actions, cardio protection and prevention of CNS damage.
The parent RVT could act as an AO, similar to the familiar phenolic $\mathrm{AO}$ vitamin $\mathrm{E}$. Also, the conjugates possessing free phenolic groups might exert $\mathrm{AO}$ effects provided contact is made with free radical species. However, conjugation with highly hydrophilic groups results in increased water solubility. An AO analog would be water soluble vitamin C.

There is scant literature on oxidative metabolism of RVT. In a metabolic study, mention is made of hydroxylation, in addition to glucuronidation, sulfation and hydrogenation. ${ }^{23}$ Oxidation catalyzed by lipoxygenase yields a complex mixture of decomposition products, similar to those obtained with hydrogen peroxide. ${ }^{24}$ Quinones, apparently not yet identified, may be formed in low yield, difficult to isolate due to reaction with protein nucleophiles. However, only small amounts are required to carry out catalytic ET with generation of large quantities of ROS.

The protective effects of RVT are demonstrated for cancer and insults to many body constituents, including the cardiovascular system, central nervous system (CNS), liver, kidney, DNA and others. There is a beneficial effect in connection with aging, arthritis and inflammation. The drug is a versatile agent that also functions through cell signaling and gene expression. Other aspects treated are metabolism, receptor interaction, electrochemistry, safety and pro-oxidant behavior. Suggestions for future work are offered.

This review demonstrates that the ET-ROS-OS-AO unifying theme, which has been successful for many other classes of drugs and toxins, can also be applied to RVT, and this comprises the first comprehensive, mechanistic review devoted to that agent. However, it should be emphasized that physiological activity of endogenous and exogenous substances is often complex and multifaceted. Our objective does not encompass extensive treatment of all other modes of action. The citations are usually representative, rather than exhaustive. A number of original references may be found in the reviews and articles cited.

\section{Metabolism}

A common metabolic route for phenols involves oxidation to catechols or hydroquinones with subsequent conversion to o- or p-quinones. An ensuing result is often redox cycling entailing oxygen with production of ROS. It is quite significant that finding comparable literature for phenolic RVT is difficult. A rationale is provided by various metabolic reports. Rapid metabolism leads to about $75 \%$ excretion in urine and feces in the form of RVT glucuronides and sulfates. ${ }^{17}$ The following conjugates are reported: 3-O-and 4'-O-glucuronides: ${ }^{18}$ most abundant, 3-O-glucuronide and 3-sulfate, ${ }^{19}$ main metabolites, monoglucuronide, dihydro monosulfate, monosulfate and dihydro RVT; ${ }^{20} 3$-sulfate, 4'-sulfate, 3,5-disulfate, 3,4'-disulfate, 3,4',5-trisulfate, 3-glucuronide and aglycone. ${ }^{21}$ In a study with two cell lines, RVT-3sulfate was identified. ${ }^{22}$ The absence of toxic effects apparently results from preferential conjugation, rather than appreciable oxidation to ET quinones.

\section{Antioxidant}

The AO property is apparently an important aspect of the physiological activity of RVT, particularly in relation to protection from oxidative injury. The literature is extensive and is also cited in other parts of this review.

The AO effect of RVT was manifested in blood mononuclear cells by a significant reduction in malonaldehyde content, an indication of oxidant injury. ${ }^{25}$ The cells acquired AO capacity. Grape RVT may be a useful dietary supplement for minimizing oxidative injury in immune-perturbed states and human chronic degenerative diseases. The effect of RVT on oxidative/ nitrative stress by peroxynitrite, which is a strong physiological oxidant and inflammatory mediator, was determined in human blood platelets. ${ }^{26}$ Protein oxidation was significantly inhibited. Oxidation of thiol groups in protein and GSH was markedly reduced. There was distinct reduction in platelets lipid peroxioxidative/nitrative damages to human platelet proteins and lipids were observed. RVT reduces OS induced by cisplatin and $\mathrm{Se}-\mathrm{Pt}$ in human blood platelets, lymphocytes and plasma. ${ }^{27}$ The AO decreased lipid peroxidation and reduced activities of anti-oxidative enzymes, such as SOD, catalase and GSH peroxidase. A significant decrease in DNA damage was observed. Another study dealt with the antioxidation and free radical scavenging activities in the protective effects on ischemia-reperfusion induced injuries of rat hearts. ${ }^{28}$ Scavenging of the stable free radical DPPH was also observed. Astringinin, a more water soluble catechol-type analog, has a superoxide scavenging ability about 160 times more potent than that of RVT, and, hence could potentially be used as an AO and cardioprotective agent in biological systems. The efficiency of RVT for protecting polyunsaturated fatty acids was higher than that of flavonoids during oxidation. ${ }^{29} \mathrm{~A}$ related study deals with inhibition of human LDL oxidation by RVT. ${ }^{30}$ The phenol exhibits potent $\mathrm{AO}$ properties related to anti-inflammatory and anti-catabolic effects. ${ }^{31}$ The findings suggest possible application of RVT in therapy of human and animal osteoarthritis. dation. Various protective effects against peroxynitrite induced 
RVT could be a useful drug for the protection of liver cells from OS induced damage. ${ }^{32}$ The phenol is of interest for its beneficial properties in a variety of pathologies, including neurodegeneration. ${ }^{33}$ Many of the beneficial effects have been attributed to the ability to reduce OS. Bioactive phenols, such as RVT, can quench ROS and thus avoid pro-oxidative damage. ${ }^{34}$ This highly effective protection against OS damage suggests that this $\mathrm{AO}$ property constitutes the major part of preventing tumor induction. An investigation was made of the mechanism of cardioprotection by RVT in ischemia-reperfusion. ${ }^{35}$ The protection of cardiomyocytes from injury occurs partly by suppression of superoxide levels via $\mathrm{AO}$ action.

The mechanism of phenolic $\mathrm{AO}$ action has been addressed in a recent book. ${ }^{16} \mathrm{~A}$ key step is stoppage of radical propagation by formation of a resonance-stabilized peroxy radical, shown in Figure 2 for RVT. A report deals with mechanism and efficiency of $\mathrm{AO}$ action involving RVT and analogs. ${ }^{36}$ The comparison of the radical-scavenging effects of RVT and its analogues trans-4-hydroxystilbene and trans-3,5dihydroxystilbene revealed that the two analogs showed almost the same effect and were more efficient than trans-3,5-dihydroxystilbene. These findings indicate greater radical-scavenging activity of the trans-resveratrol para-hydroxy group than its metahydroxy groups. Other data showed great similarity between RVT and trans-4-hydroxystilbene which seems to confirm that the para-hydroxy group of trans-resveratrol scavenges free radicals more effectively than its meta-hydroxy groups. The results can be rationalized by the greater delocalization possible for the radical from the para hydroxy group vs. the meta analog. Another important aspect entails termination of radical propagation by the phenoxy radical. This favorable aspect involves conversion to non-radical product by $\mathrm{C}-\mathrm{C}$ coupling. ${ }^{16}$ This process is reported to occur with the radical derived from RVT. ${ }^{37}$ Trapping of the radical occurs by dimerization yielding trans-delta-viniferin which is unable to chain propagate.

\section{Cell Signaling}

An investigation was made of the regulatory effect of RVT on signal transduction pathways in leukemia. ${ }^{38}$ Data indicate reduction in activation of JAK1/STAT3 tyrosine phosphorylation, as well as downregulation of expression. Evidence indicates activation of the Raf/Ras cascade and reversal of the sustained phosphorylation of JNK/SAPK. ${ }^{39}$ The study deals with the effect of RVT on signal transduction pathways involved in paclitaxelinduced apoptosis. The phenol inhibits phorbol ester activation of JNK and PKC. ${ }^{40}$ The inhibition may have a therapeutic potential, perhaps providing a novel means of controlling growth and invasiveness of tumors. A report deals with RVT modulation of phorbol ester-induced signal transduction pathways leading to elevated COX-2 expression..$^{41}$ Other signals involved are NFkappaB, MAP kinases, AP-1 and protein kinase (ERK). An overview summarizes RVT modulation of signal transduction in apoptosis and cell survival..$^{42}$ There is interference with many intracellular signaling pathways which regulate cell survival and apoptosis. Further insight is provided into the signaling network and interaction points. A review discusses the diverse molecular targets with focus on those involved in intracellular transduction. ${ }^{43}$ RVT impacts many components of intracellular signaling pathways including regulation of apoptosis and cell survival, tumor switches involved with kinases, transcription factors and their regulators. Evidence indicates that the stilbene derivative targets PTPIB to inhibit PDGFR mitogenic signaling. ${ }^{44}$ RVT mediates its effects through modulation of many different pathways by binding to numerous cell-signaling molecules..$^{45}$ The compound activates various transcription factors, e.g., NFKB, STAT3, HIF-1 $\alpha$, $\beta$-catenin and PPAR- $\gamma$, suppresses the expression of antiapoptotic gene products, inhibits protein kinases, e.g., src, P13K, JNK and AKT, induces AO enzymes, and modulates cell cycle regulatory genes. The polyphenol holds promise against numerous age-associated diseases. An investigation was made of signaling pathways influenced by RVT involved with apoptosis and growth control in leukemia. ${ }^{46}$ Apoptosis is induced by modulating three different signaling pathways that regulate cell death and survival. The survival signaling pathway Notch is inhibited. The phenol inhibits P13K/Aket and activates Gsk/3ß. Pro-apoptotic proteins p53 are also influenced. RVT reduces paclitaxel-induced apoptosis by modulating cell signaling pathways. ${ }^{39}$

Since the literature on cell signaling involving RVT is voluminous, additional, representative material is provided in abbreviated form. The organ or action is indicated along with the cell signaling involved in Tables 1-5.

In relation to mechanism at the basic level, recent proposals focus on ROS and electrochemistry. Cell signaling is known to be importantly involved in various aspects of biological function, including normal processes, therapeutic drug action and toxicology. More than 10 years ago, ROS attracted attention in relation to cell signaling. Since then several books ${ }^{103,104}$ and a book chapter ${ }^{105}$ have addressed this aspect. A recent review has further insight. ${ }^{106}$ Evidence has accumulated that ROS, such as hydrogen peroxide, superoxide, and the hydroxyl radical, are important chemical mediators that regulate the transduction of signals by 
Table 1. Apoptosis

\begin{tabular}{|c|c|c|}
\hline Cell signaling agent & Organ or action & Reference \\
\hline (1) MAP kinases & $\begin{array}{l}\text { Human breast cancer cell } \\
\text { MCF-11 }\end{array}$ & 47 \\
\hline $\begin{array}{c}\text { (2) Fas redistribution in } \\
\text { the rafts }\end{array}$ & Colon cancer cells & 48 \\
\hline (3) Ceramide & Breast cancer cells & 49 \\
\hline $\begin{array}{l}\text { (4) STAT3 and nuclear } \\
\text { factor-KB-regulation }\end{array}$ & $\begin{array}{c}\text { Human multiple myceloma } \\
\text { cells }\end{array}$ & 50 \\
\hline $\begin{array}{l}\text { (5) Protein kinases and } \\
\text { p38 kinase }\end{array}$ & Antitumor activity & 51 \\
\hline (6) Src and Stat3 & Breast cancer & 52 \\
\hline (7) TRAIL-induced & Mitochondria & 53 \\
\hline $\begin{array}{l}\text { (8) Phosphorylated Akt } \\
\text { and Caspace-9 }\end{array}$ & $\begin{array}{l}\text { MCF7 human breast cancer } \\
\text { cells }\end{array}$ & 54 \\
\hline $\begin{array}{c}\text { (9) Cdc42 activation of } \\
\text { ASK1/JNK }\end{array}$ & Human leukemia cancer cells & 55 \\
\hline $\begin{array}{c}\text { (10) Phosphatidylinositol } \\
\text { 3'-kinase Akt }\end{array}$ & Human prostate cancer cells & 56 \\
\hline $\begin{array}{l}\text { (11) WAF-1/p21- } \\
\text { mediated G phase }\end{array}$ & $\begin{array}{l}\text { Human epidermoid } \\
\text { Carcinoma A431 cells }\end{array}$ & 57 \\
\hline (12) AMPK & Colon cancer cells & 58 \\
\hline (13) JNK and c-JUN/AP-1 & Prevented HNE-induced JNK & 59 \\
\hline (14) c-Myc & $\begin{array}{l}\text { Downregulation in human } \\
\text { medulloblastoma }\end{array}$ & 60 \\
\hline (15) ERK & $\begin{array}{l}\text { Initiates p53 dependent } \\
\text { apoptosis via } \alpha \vee \beta 3\end{array}$ & 61 \\
\hline (16) Caspase-3 & Human breast cancer cell & 62 \\
\hline (17) CD95 & Human tumor cells & 63 \\
\hline (18) TNBS & Inhibiting Notch pathway & 64 \\
\hline (19) p53 and P13K/Akt & $\begin{array}{c}\text { Human T-cell acute } \\
\text { lymphoblastic leukemia } \\
\text { MOLT- } 4 \text { cells }\end{array}$ & 65 \\
\hline
\end{tabular}

Table 2. Cancer

\begin{tabular}{|c|c|c|}
\hline Cell signaling & Organ or action & Reference \\
\hline (1) NFKB and Ap-1 & Genes & 66 \\
\hline $\begin{array}{c}\text { (2) p38, MAPK, p53 and } \\
\text { p21 }\end{array}$ & Cancer cells & 67 \\
\hline $\begin{array}{c}\text { (3) NF } \alpha \text { mediated MMP-9 } \\
\text { expression }\end{array}$ & $\begin{array}{l}\text { Hepatocellular carcinoma } \\
\text { cells }\end{array}$ & 68 \\
\hline $\begin{array}{l}\text { (4) TRAIL through gene } \\
\text { expression }\end{array}$ & Human melanomas & 69 \\
\hline (5) STAT3 & Medulloblastoma cell lines & 70 \\
\hline (6) MAPK & Breast cancer cells & 71 \\
\hline $\begin{array}{c}\text { (7) c-Jun-NH2-terminal- } \\
\text { kinase }\end{array}$ & $\begin{array}{l}\text { Waldenström's } \\
\text { macroglobulinemia }\end{array}$ & 72 \\
\hline (8) NFKB & $\begin{array}{c}\text { Cardiovascular, } \\
\text { neurological and } \\
\text { mitochondrial dysfunction }\end{array}$ & 73 \\
\hline (9) ATM/ATR-Chk1/2-Cdc42 & Ovarian cancer cells & 74 \\
\hline (10) Rac and Cdc42 & Breast cancer cells & 75 \\
\hline (11) P13K & Cultured muscle cells & 76 \\
\hline
\end{tabular}

modulating protein activity via redox chemistry. Authors have proposed that ROS have been conserved throughout evolution as universal second messengers. Nearly every step in signal transfer is sensitive to ROS, which can function as second messengers in the activation of transcription factors. Various types of radiation, which are generators of ROS, also influence cell communications. Since the messengers must possess appreciable lifetime in order to migrate, a certain degree of stability is required. For example, the hydroxyl radical would not be a messenger due to its extremely high reactivity with its resultant very short time existence, although it would generate messenger radicals. Likely candidates include superoxide and resonance stabilized peroxyl radicals. Others would be stable ROS arising from AOs, such as vitamin $\mathrm{C}$, vitamin $\mathrm{E}$ and flavonoids. Members can be envisioned from the reactive nitrogen species (RNS) category. NO is a well known radical that plays an important role in cell signaling. In relation to theory, a puzzling aspect is its relatively short life time. Perhaps more stable complexes are involved. Other nitrogen radicals can play a role. Important candidates comprise small proteins possessing redox groups.

In effect, cell signaling can be regarded as proceeding via a long redox chain in which the standard parameters of initiation, propagation and termination pertain, involving omnipresent conduit species with unshared electrons. A series of relay stations may be operative. Based on the redox chain framework, the second messenger might be superoxide formed by redox process involving oxygen and a second messenger electron from an ET functionality in the receptor site. At the termination of the initial journey, radical character would be transmitted to a site, mobile or stationary, e.g., a redox amino acid (AA) side chain acting as a relay (transfer station), that could then pass on (initiate) radical character to a third messenger. These types of interactions, widespread in AA chemistry, usually involving electron and/or hydrogen abstraction to generate radical species, are treated in a review. ${ }^{107}$ The numerous redox moieties in anchored proteins might fall in the relay category. There has been dramatic increase in attention devoted to free radical species in cell signaling, although the bulk of the signal transduction literature pays no attention to this aspect.

Electrochemistry also appears to play a role in cell signaling, including electron transfer and electrostatics. Discussion is present in recent reviews on receptor-ligand activity, ${ }^{108}$ phosphates and sulfates ${ }^{109}$ and metal cations. ${ }^{110}$

\section{Receptors}

The literature on the RVT receptor is very limited. RVT is a phytoestrogen which binds to and activates estrogen receptors that regulate the transcription of estrogen-responsive target genes. ${ }^{111}$ The effect on gene expression appears to correlate with chemoprevention. The drug regulates mRNA expression of several genes involved in cell cycle control, apoptosis, metastasis, cellcell adhesion and receptor signaling pathways. A report shows RVT binds to the sulfonyl urea receptor. ${ }^{112}$ Electrophysiological measurements revealed that the bound ligand is a blocker of pancreatic SUR channels and enhances apoptosis. RVT is known to 
influence the androgen receptor (AR). AR pathways are involved in the development and progression of prostate cancer. ${ }^{113}$ The ability to modulate AR function may contribute to the chemopreventive activity of RVT. Also, the drug regulates AR target gene expression, at least in part, by repressing AR transcriptional activity. ${ }^{114,115}$ RVT represses different classes of AR. AR upregulates genes at the protein or mRNA level, and may be a useful preventive or therapeutic agent for prostate cancer. ${ }^{116}$ Aryl hydrocarbon receptor ligands, such as dioxin and polynuclear aromatic hydrocarbons, are environmental contaminants with many adverse effects. ${ }^{17}$ RVT, a competitive antagonist of these ligands, promotes receptor translocation to the nucleus and binding to DNA. The phenol inhibits the transactivation of several dioxin-inducible genes. Clinical testing as a prophylactic against the insults is warranted.

\section{Electrochemistry}

Glucose-induced depolarization was counteracted by RVT. ${ }^{118}$ There is inhibition of electrical activity and insulin release from insulinoma cells by blockage of voltage-gated Ca channels and chloride currents, with inhibition of K (ATP) currents. RVT inhibits the electrical activity of paraventricular nucleus neurons and exerts neuroprotective effects on central neurons. ${ }^{119}$ The effects of RVT on neuron discharges in rat subfornical organ were examined. ${ }^{120}$ The inhibition of electrical activity may be related to blockade of voltage-gated Ca channels and NO promotion. A study demonstrated RVT-induced depression of electrical activity in the rat heart. ${ }^{121}$ The shortened action potential in the left atrium is likely due to activation of K (ATP) channels. The importance of electrochemistry in living systems has been reviewed recently. ${ }^{122}$

\section{Aging}

The anti-aging property of RVT has enjoyed much attention. This aspect is also addressed in many other portions of this review. Considerable prior literature identifies ROS with the aging process.

An article deals with prevention and treatment of common clinical conditions of aging. ${ }^{123}$ Aging is associated with a variety of common conditions, such as cancer, diabetes, cardiovascular disease and Alzheimer's disease. Properties of the phenol associated with the beneficial aspects include $\mathrm{AO}$, regulation of the cell cycle, activation of intracellular pathways, vascular tone, oncogene suppression and mitochondrial energy production. There is a striking transcriptional overlap of RVT and calorie restriction in the heart, skeletal muscle and brain. ${ }^{124}$ Both interventions inhibit gene expression associated with cardiac and skeletal muscle aging, as well as prevention of cardiac dysfunction. RVT fulfills the definition of a dietary compound that mimics some aspect of calorie restriction. A review summarizes the anti-aging properties of RVT, including cardiovascular benefits via increased NO production, downregulation of vasoactive peptides, lowered levels of oxidized low-density lipoprotein, cyclooxygenase inhibition, effects on neural tissues,
Table 3. Inflammation

\begin{tabular}{|c|c|c|}
\hline Cell signaling agent & Organ or action & Reference \\
\hline (1) NFKB & $\begin{array}{c}\text { Chromatin structure } \\
\text { Glutathione biosynthesis }\end{array}$ & 77 \\
\hline (2) IL-6-induced ICAM-1 & $\begin{array}{l}\text { gene expression in } \\
\text { endothelial cells }\end{array}$ & 78 \\
\hline $\begin{array}{c}\text { (3) P13KK/AKt/ERK } \\
\text { dependent interleukin IL-17 }\end{array}$ & Mouse cardiac fibroblast & 79 \\
\hline (4) $\mathrm{TNF} \alpha$ & Endothelial cells & 80 \\
\hline (5) Cytokine $1 \mathrm{~L}-1 \beta$ & Human chondrocytes & 81 \\
\hline (6) $N F \kappa B$ and $A P-1$ & Mouse skin cell & 82 \\
\hline (7) TLR-derived & $\begin{array}{l}\text { Mouse embryonic } \\
\text { fibroblast }\end{array}$ & 83 \\
\hline
\end{tabular}

phytohormonal actions, anticancer properties via modulation of signal transduction (anti-initiation, antipromotion and antiprogression effects), antimicrobial effects, sirtuin activation, possible benefits in Alzheimer's disease and prevention of photoaging. ${ }^{125}$ Comparison was made with other AOs used in skin care products. RVT consistently retards aging in organisms as diverse as yeast, worm, fly and fish. ${ }^{126}$ It prolonged lifespan and delayed the onset of age-related dysfunctions in fish. A review focuses on the role of OS and inflammation in cardiovascular dysfunction in aging, and on emerging anti-aging therapeutic strategies offered by RVT and other polyphenols. ${ }^{127}$ In a study of RVT influence on aging, the drug mitigated the metabolic dysfunction of mice fed high-fat diets. ${ }^{128}$ The effects may be mediated partly by activation of a deacetylase enzyme that regulates several transcription factors and enzymes responsive to nutrient availability.

\section{Cancer}

Antioxidant. OS arising from ROS appears to be associated with many aspects of carcinogenesis. ${ }^{4}$ For example, there is involvement in three major stages of the process. Literature cited ${ }^{129-134}$ indicates that RVT as an AO provides a beneficial effect in alleviation of harmful OS. In some cases, there is evidence for significant modulation of oxidative imbalance and effect on levels of other AOs.

Apoptosis. Apoptosis plays a part in many aspect of biological chemistry. There are many articles which deal with it in connection with cancer. The reports addressed herein do so in connection with presence of RVT. ${ }^{62,135-149}$

Cell signaling. This aspect has been addressed in a general approach (see above). Cell signaling has played a role in many aspects of biochemistry. It is not surprising that considerable attention has been devoted to its relationship with cancer. Mechanistic aspects of signaling are summarized in an above section. Representative articles are provided that involve $\mathrm{RVT}^{4}{ }^{43,58,150-158}$

Nitric oxide. This fascinating gas possesses a wide variety of bioactivities, both beneficial and deleterious. Many modes of action have been implicated. One review puts focus on electron transfer. ${ }^{159}$ Peroxynitrite formed by reaction with superoxide, 
Table 4. Heart

\section{Cell signaling agent}

(1) AMPK

(2) NFKB

(3) p38 and ERK/1/2

(4) p38 Mitogen-activated protein kinase

(5) $\mathrm{BCl}-2$

(6) p38 map kinase and P1-3-kinase

(7) Akt/protein Kinase B

\section{Organ or action}

$\mathrm{H} 9 \mathrm{c} 2$ cardiac muscle cells

Endothelial cells of coronary artery

Inhibits EMMMPRIN THP-1 cells

Triggers an MAPK path involving ERK $1 / 2$ and P38 MAPK

Adenosine $\mathrm{A}_{3}$ receptor Activation

HO-1 mediated mechanism

Suppresses angiotensin II-induced protein
Reference

84

85

86

87

88

89

90
Table 5. Miscellaneous

\begin{tabular}{|c|c|c|}
\hline $\begin{array}{l}\text { Cell signaling } \\
\text { agent }\end{array}$ & Organ or action & Reference \\
\hline (1) NF-E2 & HO-1 gene expression & 91 \\
\hline (2) Kinase & $\begin{array}{l}\text { Reduces oxidation of human retinal } \\
\text { pigment epithelial cells }\end{array}$ & 92 \\
\hline (3) AMPK & Antidiabetic & 93 \\
\hline (4) Nrf2 & Cigarette smoke-mediated OS & 94 \\
\hline $\begin{array}{l}\text { (5) SIRT1 and } \\
\text { AMP kinase }\end{array}$ & Human alcoholic liver disease & 95 \\
\hline (6) Ras & $\begin{array}{l}\text { Stimultes sirtuins and extends life } \\
\text { span }\end{array}$ & 96 \\
\hline (7) Caspase-3 & Inhibits IL-1 $\beta$-induced stimulation & 97 \\
\hline (8) 3-Kinase/Akt & $\begin{array}{l}\text { Inhibition of phosphor-inositide- } \\
\text { dependent kinase-1 activity }\end{array}$ & 98 \\
\hline (9) NFKB & $\begin{array}{l}\text { Stimulates cytokines IL-6-1 } \beta \text { and } \\
\text { NFKB }\end{array}$ & 99 \\
\hline (10) P13K & Inhibition & 100 \\
\hline (11) AMP kinase & Stimulate AMPK in neurons & 101 \\
\hline $\begin{array}{l}\text { (12) NFKB and } \\
\text { AP-1 }\end{array}$ & $\begin{array}{c}\text { Activate and regulate gene } \\
\text { expression }\end{array}$ & 67 \\
\hline (13) MAPK & Activate through estrogen receptors & 102 \\
\hline $\begin{array}{l}\text { (14) NFKB, } \\
\text { STAT3, HIF-1 } \alpha\end{array}$ & Activate transcription factors & 45 \\
\hline
\end{tabular}

plays a role, particularly in toxicity. A sampling of literature is presented for the effects of NO along with RVT. ${ }^{135,160,161}$

Miscellaneous aspects. There are many other approaches that deal with the cancer problem, along with involvement of RVT. ${ }^{162-174}$ Examples involve hormones, polyamines, autophagy, cathepsin D, DNA synthesis and mitochondria.

\section{Cardiovascular System}

RVT displays many bioactivities, such as protection from or reduction of the incidence of coronary heart disease, including counteraction to ischemia-reperfusion injury. ${ }^{175}$ It might be that there is inhibition of signaling pathways and gene expression which involve the disruption of the ERK pathway via attenuation of ROS. A review focuses on the role of the phenol on OS and inflammation in cardiovascular disease. ${ }^{176}$ Intake may contribute to the "French paradox" involving the unexpectedly low cardiovascular morbidity in the Mediterranean population, which may reflect the $\mathrm{AO}$ and anti-inflammatory effects. Upregulation of NO production might also be involved. ${ }^{177}$ The amount of malondialdehyde, indicative of lipid peroxidation, was decreased in the postischemic myocardium indicating a reduction of OS. ${ }^{178}$ There was prevention of superoxide-dependent inflammation response induced by ischemia-reperfusion and oxidants. ${ }^{179} \mathrm{AO}$ properties may be involved. RVT exhibits multifaceted properties in preventing various harmful vascular alterations, in addition to aging, including cell signaling, enzymatic pathways, apoptosis, gene expression and $\mathrm{AO}$ action. ${ }^{180}$ The review discusses the relationship with ROS and regulation of pro-inflammatory genes. Administration of RVT exerts cardioprotection against ROS-mediated menadione toxicity. ${ }^{181}$ Results indicate that the drug interferes with the release of inflammatory mediators, thus providing biological plausibility to the protective effect of moderate red wine consumption against coronary heart disease. ${ }^{182}$ In a related study a protective AO effect of RVT in red wine was demonstrated against oxidative injury on red blood cells. ${ }^{183}$ Authors proposed that the $\mathrm{AO}$ and antiapoptotic effects, together with the anti-inflammatory actions, are responsible, at least in part, for the cardioprotective effects. ${ }^{184}$ Upregulation of endogenous AOs and certain enzymes by red wine RVT in aortic muscle cells leads to protection against oxidative and electrophilic stress. ${ }^{185}$ Various investigations dealt with the effects on blood platelets, such as, action as $\mathrm{AO}$ for reduction of OS, ${ }^{186}$
Figure 3. Resveratrol quinone. This stilbene quinone would be expected from facile oxidation of RVT. However, we are unable to find any report of its formation. It may be that it is present only in very small amounts making for greater difficulty in isolation. Nevertheless, only minor quantities will suffice for the catalytic generation of large amounts of ROS. Quinone formation is one rationale for the observed pro-oxidant effects of RVT involving redox cycling with oxygen leading to ROS. 
inhibition of superoxide generation, ROS production and lipid peroxidation. ${ }^{187}$ The drug reduces ROS levels, blunts the inflammatory pathways and stimulates NO generation. ${ }^{188}$ There is inhibition of ROS production, e.g., superoxide, hydrogen peroxide, singlet oxygen and organic radicals, ${ }^{189}$ and a variety of actions including anti-inflammatory, $\mathrm{AO}, \mathrm{ROS}$, scavenger and reduction of lipid peroxidation. ${ }^{190}$

A prior comprehensive review on prevention of cardiotoxicity is based on the unifying theme of ET-ROS-OS. ${ }^{8}$

\section{Central Nervous System (CNS)}

Much research supports the thesis that ROS play a role in insults to the CNS.9 Since the brain is deficient in defenses by AOs, supplementation should be investigated as a potential clinical approach. There are many reports demonstrating the beneficial effect of RVT in preventing toxic attacks in relation to brain neuronal injury in conditions such as Alzheimer's disease and Parkinson's disease. ${ }^{11-199}$ In many cases, attribution is given to the $\mathrm{AO}$ property. In the treatment of traumatic brain injury, the drug provided neuroprotection by reducing OS. ${ }^{200}$ There is a related report. ${ }^{201}$ Increased OS has been implicated in the mechanism of neuronal cell death following cerebral ischemic insult. ${ }^{202,203} \mathrm{RVT}$ exerted a protective action, apparently as an AO. The phenol is a potent neuroprotective agent against diabetic oxidative damage. ${ }^{204}$ There was reduction in lipid oxidation product and NO production, as well as OS and DNA fragmentation. ${ }^{205}$ A neuroprotective effect via free radical scavenging was observed with induced Parkinsonism. ${ }^{206,207}$ Intervention by AOs can be a potential beneficial approach in the treatment of epilepsy. ${ }^{208}$ The protective effect of RVT against kainic acid-induced convulsions and the attenuation of lipid oxidation product suggest the potential use of AOs as adjunct therapy in epilepsy. The neuroprotective ability of RVT against NO-related toxicity in hippocampal neurons is attributed to AO involvement. ${ }^{209}$ Also, a neuroprotective effect was observed in cerebral ischemia. ${ }^{210}$ There was decrease in product from lipid oxidation and induction of an important role for NO.

\section{Inflammation}

An appreciable amount of research is reported on the anti-inflammatory effects of RVT. Evidence shows that the condition is associated with the presence of ROS. ${ }^{15}$ Hence, it is not surprising that the powerful phenolic AO exerts a beneficial effect. Literature in the area is also discussed elsewhere in this review, such as in cell signaling.

Some research in this area involves the lungs. ${ }^{211} \mathrm{~W}$ ith human airway epithelial cells, RVT inhibits NFKB-protein dependent transcription and cytokine-stimulated inducible $\mathrm{NO}$ synthase cells. The salutary effects of the drug on attenuation of lung

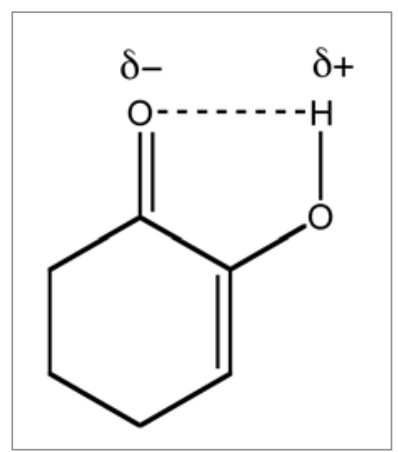

Figure 4. Enol tautomer of cyclohexane-1,2-dione. Although the keto form is generally favored over the enol tautomer, in the case of " 4 ," hydrogen bonding of enol with the carbonyl results in increased contribution of enol to the equilibrium state.

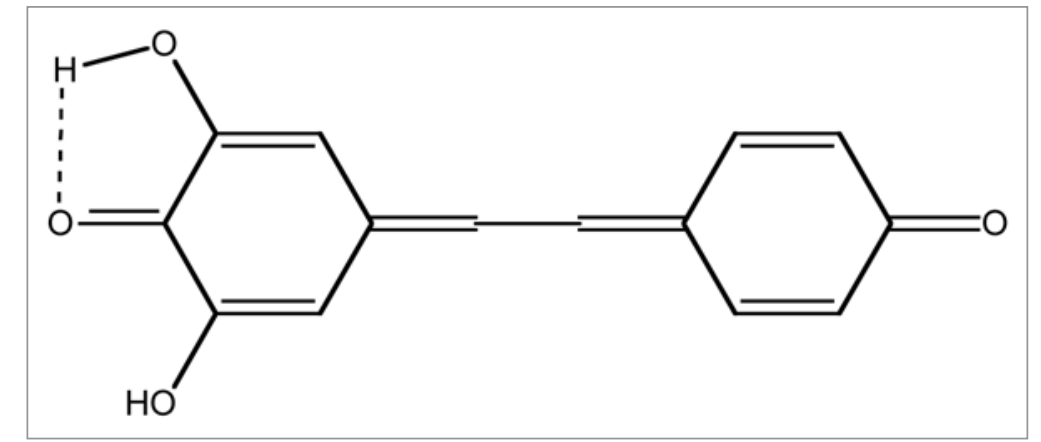

Figure 5. Mono-hydrogen bonded quinone. This structure is analogous to that in Figure 4. Hence, the enol moiety is stabilized.

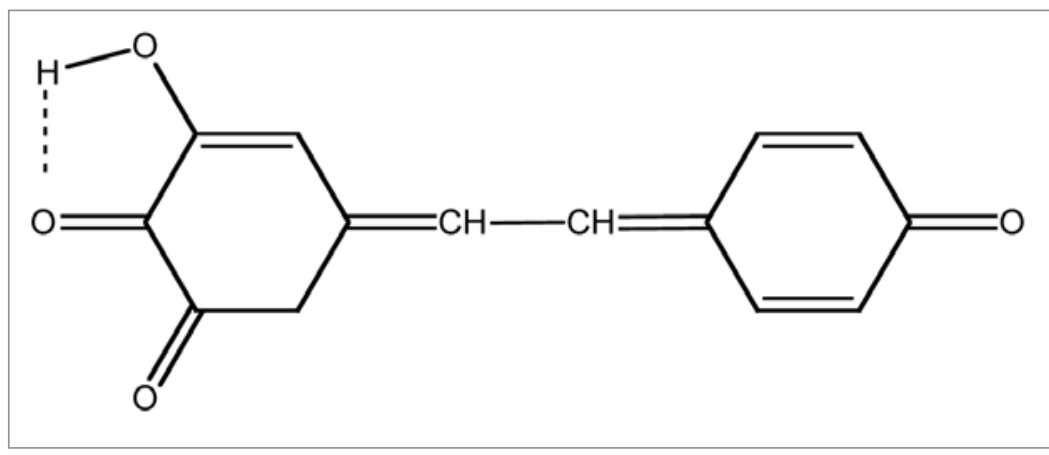

Figure 6. Diketo-enol tautermer of " 3 " (Fig. 3). Structure " 5 " (Fig. 5) shows the stabilization of an enol group by H-bonding, similar to that in "4" (Fig. 4). Since this is now less likely for the other enol group. It may tautomerize mostly to the keto form as illustrated in "6" (Fig. 6). The ability to redox cycle would be substancially decreased due to absence of the quinone functionality. The conjugated $\alpha$-dicarbonyl structure in " 6 " (Fig. 6) should be capable of electron uptake, but not be a good generator of ROS.

injury following trauma hemorrhage are likely due to reduction of pro-inflammatory mediators. ${ }^{212}$ Plausible mechanisms of anti-inflammatory activity are discussed. ${ }^{213}$ This property may have relevant clinical implications. The drug could alleviate the 


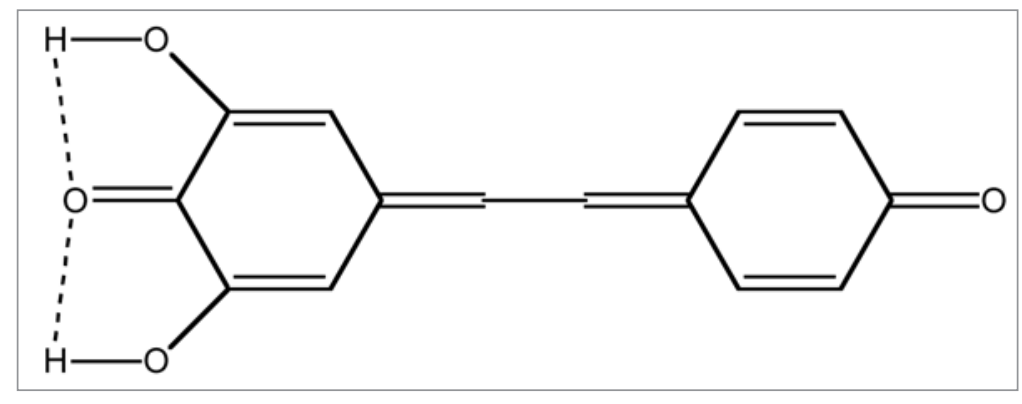

Figure 7. Di-hydrogen bonded quinone. Perhaps both enols participate in $\mathrm{H}$ bonding with the carbonyl. Therefore, the quinone structure is maintained.

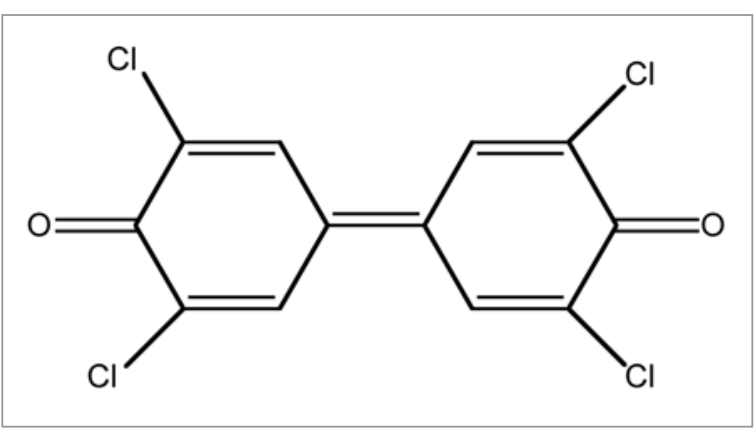

Figure 8. Quinone metabolite of PCB. This metabolite route to " 8 " is quite similar to that proposed for RVT, which provides support for the proposed oxidative metabolism. The monohydroxy metabolite of PCB is analogous to RVT.

severity of pancreatitis through its anti-inflammatory effects, regulation of inflammatory mediators and inhibition of NFKB expression. ${ }^{214}$ Also, there is prevention of superoxide-dependent inflammatory response induced by ischemia/reperfusion platelet-activating factor or oxidants. ${ }^{215}$ The phenol decreases the degree of inflammation associated with colitis. ${ }^{64}$ The effect may result from the countering of OS and proinflammatory cytokines. Attenuation of ischemia/reperfusion injury in rats is due to the ant-inflammatory action of RVT, apparently through a NO-dependent mechanism. ${ }^{216}$

\section{Arthritis}

Much evidence supports a role for ROS-OS in arthritis. ${ }^{15}$ This includes oxidative damage to DNA, protein and lipids. In accord with involvement of ROS, there is depletion of GSH, ascorbate and $\alpha$-tocopherol. Hence, it is not surprising that the AO RVT possesses the potential for arthritis treatment. ${ }^{217}$ Inflammation, which is commonly associated with arthritis, appears to have a ROS link. ${ }^{15}$ Involvement of cell signaling pathways is also treated. ${ }^{217}$ The inflammatory process plays a pivotal role during the pathogenesis of osteroarthritis, dominated by catabolic processes initiated by pro-inflammatory cytokines, such as IL-1 beta. ${ }^{218}$ RVT appears to be an effective anti-inflammatory agent that has a chondroprotective capacity through suppression of IL-1 $\beta$, ROS and tumor suppression protein p53 production.
$\mathrm{NF \kappa B}$ is a pivotal transcription factor involved in the activation of the TNF $\alpha$ and IL- $\beta$ genes. ${ }^{219}$ Activation of NFKB is a feature seen in arthritis patients. RVT is a potent and specific inhibitor of TNF $\alpha$ and IL-1 $\beta$. Injection of the drug may protect cartilage against the development of inflammatory arthritis.

\section{Liver}

Pyrogallol causes hepatotoxicity in experimental animals. ${ }^{220}$ RVT reduces the increase in lipid peroxidation due to OS by the toxicant. The accompanying decrease in GSH, GSH peroxidase and GSH reductase activities was significantly attenuated by the phenol. In a study of the liver damage with a high-fat diet, RVT reduces oxidized LDL and hepatic OS. ${ }^{221}$ RVT-mediated chemoprevention of hepatocarcinogenesis occurred with nitrosamine-initiated carcinogenesis. ${ }^{222}$ The favorable effect was attributed to inhibition of cell proliferation and induction of apoptosis. A review documents evidence for the favorable effect entailing destruction of cancer-initiating ROS by $\mathrm{AO}$ action (see Introduction). Liver damage caused by chronic alcohol consumption was reduced by RVT. ${ }^{223}$ Inhibition of oxidation of polyunsaturated fatty acids is proposed as a basis of the hepatoprotective effect. The involvement of OS in the pathogenesis of alcoholic diseases in the liver has been repeatedly confirmed. ${ }^{224}$ Dietary supplementation with RVT during ethanol treatment inhibited hepatic lipid peroxidation and ameliorated the reduction in activity of SOD, catalase and GSH peroxidase.

\section{Kidney}

The protective effect of the $\mathrm{AO}$ resveratrol and others was investigated in the kidney of rats treated with the carcinogen $\mathrm{KBrO}_{3}{ }^{225}$ The $100 \%$ increase in $8-\mathrm{OH}-\mathrm{dG}$ from oxidation in the renal genome DNA was completely abolished by treatment with RVT. ROS have been implicated in cell injury that occurs after ischemia. ${ }^{226}$ Products of lipid peroxidation are generated on reperfusion. This oxidation can be prevented by AOs. Resveratrol was found to exert a favorable effect in reducing such injury. A related report is available. ${ }^{227}$ An hypothesis was advanced concerning the beneficial effects of red wine which contains resveratrol. ${ }^{228}$ Evidence suggests a protective role of moderate wine consumption against the onset and progression of renal diseases, based on the concept of kidney injury mediated by OS. A similar study was reported. ${ }^{229}$ ROS are observed in gentamicin-induced nephrotoxicity. ${ }^{230}$ Renal lipid peroxidation increases with the toxicant alone, which was prevented by the administration of RVT. ${ }^{230}$ Addition of the phenol resulted in an increase in the levels of AOs. At least a part of the favorable effects was attributed to the $\mathrm{AO}$ activity.

\section{DNA}

RVT reduces nuclear DNA fragmentation. ${ }^{231}$ Results indicate that the drug can act as an antimutagenic/anticarcinogenic agent 
by preventing DNA damage which plays a pivotal role in the carcinogenic activity of many genotoxic agents. The phenol reduced DNA damage induced by $\mathrm{Cr}$ (III) based on reduced 8-OH-dG formation. ${ }^{232}$ The protective effect against $\mathrm{Cr}$-induced carcinogenesis may relate to the free radical-scavenging ability. The genoprotective effects of the drug were investigated under conditions of OS induced by hydrogen peroxide in glioma cells. ${ }^{233}$ Due to attenuation of oxidative DNA damage, RVT may be important in protecting against DNA fragmentation and oxidation arising from OS. In a study of Alzheimer's disease, red wine micronutrients were found protective. The phenols reduced ROS production, prevented DNA fragmentation and protected the cellular membrane from oxidative damage.

\section{Genes}

RVT significantly blocked the expression of genes related to the NFKB family. ${ }^{234}$ The phenol has a significant modulatory effect on the NFKB signaling pathway and an important $A O$ role that may help explain the cardioprotective effects attributed to long-term moderate red wine consumption. Through its phytoestrogenic properties, RVT regulates the expression of hormonedependent genes in breast cells and provides a protective effect against several types of cancer, notably breast cancer. ${ }^{111}$ The drug modulates the expression of genes in a pattern dependent on the state of estrogen receptors. Gene expression is regulated via the estrogen receptor pathway and also an undetermined pathway. The effects of RVT on circadian clocks of Rat-1 cells were analyzed. ${ }^{235}$ A dose, which did not exhibit toxicity, regulated the expression of various clock genes. Relevant material is also present elsewhere in this review.

\section{Other Body Constituents}

In addition to the extensive studies presented in the above sections, there are many reports of the beneficial effects of RVT on other body constituents under stress. Much of the salutary responses can be attributed to AO action under OS. RVT limited dysfunction of rat brain mitochondria in an anoxia-reoxygenation model. ${ }^{236}$ At least three mechanisms were proposed, including AO properties. Data indicate that the drug may have application in the treatment of bronchial asthma, accompanied by inhibition of increases in cytokinases. ${ }^{237} \mathrm{~A}$ review provides evidence for $\mathrm{AO}$ protection of various pulmonary disorders. ${ }^{13}$ The phenol exerted beneficial activity against alcohol injury, e.g., peroxidation of lipids. ${ }^{238}$ The adverse effects, countered by AO action involve ROS and OS. Oxidative stress entailing rapid degeneration of endothelial cell function, is deeply involved in systemic sclerosis pathogenesis. ${ }^{239}$ There is potential for RVT as an AO for reverting endothelial dysfunction, scavenging lipid peroxides and reducing hypoxia-reperfusion injury. Examination revealed a significant improvement in ovarian morphology in RVT-treated rats, compared with the ischemia-reperfusion group. ${ }^{240}$ Drug administration reduced lipid peroxide products and countered the reduction in GSH levels. The phenol exerted a favorable influence against lipid peroxidation in cell membranes, including a decrease in DNA damage. ${ }^{241}$ An important AO role was assigned. Also, an inhibitory effect was observed on the NFKB signaling pathway after exposure to metal-induced radicals. Obesity in the US has become a serious problem, leading to a sharp increase in diabetes. In a controlled study, RVT treatment caused the greatest and most consistent loss of fat content in animal subjects. ${ }^{242}$ The underlying target protein likely involves sirtuin family members. A study was carried out involving RVT and Cd-induced oxidative damage in mice. ${ }^{243}$ The phenol and other AOs effectively protect against lipid peroxidation generated by the metal, and were able to counter the inhibition of catalase activity. Metals are well-known generators of ROS and OS. ${ }^{2-15}$

Skin cancer is a common illness among humans, due to solar radiation. ${ }^{243} \mathrm{~A}$ way to reduce the occurrence is by use of photochemopreventive agent, often in the AO category. ${ }^{244}$ Results suggest that RVT may afford substantial protection against damage caused by UVB exposure, which may be mediated via its $\mathrm{AO}$ properties. RVT reduces colitis, alleviates oxidative events and stimulates apoptosis. ${ }^{245}$ Much attention has recently been paid to nanoparticles. RVT-loaded nanoparticles protected cells from $\beta$-amyloid peptide toxicity by attenuating intracellular OS and caspase-3-activity. ${ }^{246}$ A review addresses various approaches to immunomodulation. ${ }^{247}$ Disruption of the accompanying proinflammatory cascade is by various therapies, including RVT, involving various mechanisms, including $\mathrm{AO}$ effects and alterations in cell signaling.

\section{Pro-Oxidant}

The literature contains extensive documentation for $\mathrm{AO}$ action by RVT as presented above. However, there is an apparent dichotomy based on an appreciable number of reports providing evidence for pro-oxidant action. The following material addresses these references, followed by rationale for the dichotomy.

Compounds, such as RVT, acting as AOs to lipids often have a pro-oxidant effect on DNA or protein. ${ }^{248}$ Free radicals derived from the phenol appear to mediate between anti-and pro-oxidative actions. Dietary polyphenols with phenol rings are metabolized by peroxidase to form pro-oxidant phenoxy radicals which are sufficiently reactive to co-oxidize GSH or NADH accompanied by extensive oxygen uptake and ROS formation. ${ }^{249}$ The experimental conditions are important for the pro-oxidant activity, causing oxidative DNA damage that may lead to cell cycle arrest or apoptosis. ${ }^{250}$ At certain concentrations, RVT elicits pro-oxidant properties as evidenced by an increase in intracellular superoxide. ${ }^{251}$ The pro-oxidant effect is further supported by other observations. An unusual study reveals opposite effects on rat tissue lipid peroxidation. ${ }^{252}$ With a dark-light cycle, RVT behaved as an AO during the dark span, and as a pro-oxidant during the light span, comprising further support for the importance of conditions.

Discussion of the AO-pro-oxidant aspect is available for other well-known AOs, such as vitamins $\mathrm{E}$ and $\mathrm{C}$, flavonoids and thiols. ${ }^{16}$ For the phenols, a pro-oxidant appears to involve conversion to a quinone capable of ET-ROS-OS. A similar route would apply to RVT in relation to oxidation to the stilbene quinone " 3 " (Fig. 3). However, we have not found such a report (see Metabolism 
section). It may be that the quinone has not yet been isolated due to formation in small quantities with much being tied to protein by nucleophilic attack (see Future Work).

A superficial approach might lead to assignment of quinone " 3 " (Fig. 3) as the product from oxidation of "1." However, application of basic principles of organic chemistry could lead to different conclusion. Compound " 3 " (Fig. 3) is a conjugated dienone incorporating two enol groups. Generally, at equilibrium, the keto state is energetically favored over the enol tautomer. An exception is cyclohexane-1,2-dione for which enol "4" (Fig. 4) makes a substantial contribution due to enol stabilization by hydrogen bonding with the carbonyl..$^{253}$ It is reasonable to apply this reasoning to " 3 " (Fig. 3) as shown in structure " 5 " (Fig. 5). On the other hand, such interaction makes similar H-bonding by the other enol less likely. As a result, the keto form shown in "6" (Fig. 6) could prevail. Therefore, the quinonoid structure capable of redox cycling with generation of toxic ROS would not pertain. This scenario is in line with the very low toxicity exhibited by RVT. ${ }^{1}$ Another possibility is H-bonding involving both enol groups, as illustrated in "7" (Fig. 7), or conversion to an ET o-quinone via oxidation of adjacent hydroxyl groups in the tetrahydroxy precursor of "3" (Fig. 3).

It should be recognized that "6" (Fig. 6) could also be capable of electron uptake, but less efficiently than the related quinone. Compound "6" (Fig. 6) is a conjugated analog of diacetyl which is electron affinic, but exhibits negligible ability to generate significant OS via ROS. ${ }^{253}$

The placement of the hydroxyl groups apparently is beneficial due to phenolic $\mathrm{AO}$ action, but largely avoids the damaging redox cycling that often results from quinone generation via oxidation. This represents another example of a clever strategy employed in the biochemical domain.

Analogy can be made to metabolism of PCBs, in which oxidation proceeds via mono- and di-hydroxyl derivatives to the quinone "8" (Fig. 8) stage. Compound "8" (Fig. 8) is known to redox cycle with formation of ROS which appear responsible for some of the toxicity. ${ }^{254}$

An alternate interpretation exists for the pro-oxidant behavior. Phenols, including RVT, form complexes with metals. In the case of heavier metals, the favorable reduction potential can lead in vivo to redox cycling involving oxygen with formation of ROS leading to OS..$^{2-15}$ In the presence of $\mathrm{Cu}$ ions, DNA damage by RVT occurs which is attributed to oxidative intermediates formed by redox cycles involving the metal complex. ${ }^{255}$ Similar studies were made. ${ }^{256-261}$

\section{Future Work}

A principal aspect of metabolism (see above) involves formation of conjugates. It would be helpful to ascertain whether or not the mono- and di-derivatives with at least one free phenolic group possess $\mathrm{AO}$ properties. A careful analysis of metabolic products from oxidation should be performed with the aim of detecting the proposed quinone. Authentic material would be synthesized for comparison. Also, it could be illuminating to oxidize 1 at the carbon between the resorcinol hydroxyl groups and determine the structure in relation to the hypothetical quinone. Computational studies should cast light on the structure of “3” (Fig. 3).

\section{Other Aspects}

Related articles are available, including ones dealing with antioxidants. ${ }^{262-271}$

\section{Acknowledgements}

Editorial assistance by Thelma Chavez is acknowledged.

\section{References}

1. Udenigwe CC, Ramprasth VR, Aluko RE, Jones PJ. Potential of resveratrol in anticancer and anti-inflammatory therapy. Nutr Rev 2008; 66:445-54.

2. Kovacic P, Becvar LE. Mode of action of anti-infective agents: emphasis on oxidative stress and electron transfer. Curr Pharm Des 2000; 6:143-67.

3. Kovacic P, Osuna JA. Mechanisms of anticancer agents: emphasis on oxidative stress and electron transfer. Curr Pharm Des 2000; 6:277-309

4. Kovacic P, Jacintho JD. Mechanism of carcinogenesis: focus on oxidative stress and electron transfer. Curr Med Chem 2001; 8:773-96.

5. Kovacic P, Jacintho JD. Reproductive toxins: pervasive theme of oxidative stress and electron transfer. Curr Med Chem 2001; 8:863-92.

6. Kovacic P, Sacman A, Wu-Weis M. Nephrotoxins: widespread role of oxidative stress and electron transfer. Curr Med Chem 2002; 9:823-47.

7. Poli G, Cheeseman GH, Dianzani MU, Slater TF. Free Radicals in the Pathogenesis of Liver Injury. Pergamon Press, Oxford 1989; 1-330.

8. Kovacic P, Thurn LA. Cardiovascular toxins from the perspective of oxidative stress and electron transfer. Curr Vasc Pharmacol 2005; 3:107-17.

9. Kovacic P, Somanathan R. Neurotoxicity: the broad framework of electron transfer, oxidative stress and protection by antioxidants. Curr Med Chem-CNS Agents 2005; 5:249-58
10. Kovacic P, Pozos RS, Somanathan R, Shangari N, O’Brien PG. Mechanism of mitochondrial uncouplers, inhibitors and toxins: focus on electron transfer, free radicals and structure-activity relationships. Curr Med Chem 2005; 5:2601-23.

11. Kovacic P, Cooksy AL. Unifying mechanism for toxicity and addiction by abused drugs: electron transfer and reactive oxygen species. Med Hypotheses 2005; 64:357-66.

12. Kovacic P, Somanathan R. Ototoxicity and noise trauma: electron transfer, reactive oxygen species, cell signaling, electrical effects and protection by antioxidants: practical medical aspect. Med Hypotheses 2008; 70:914-23.

13. Kovacic P, Somanathan R. Pulmonary toxicity and environmental contamination: radicals, electron transfer, and protection by antioxidants. Reviews of Environmental Contamination and Toxicology, Ed. Whitacre WD, Springer, New York 2009; 201:41-69.

14. Kovacic P, Somanathan R. Intergrated approach to immunotoxicity: electron transfer, reactive oxygen species, antioxidants, cell signaling and receptors. J Recept Signal Transduct 2008; 28:323-46.

15. Halliwell B, Gutteridge JMC. Free Radicals in Biology and Medicine. Oxford University Press, New York 1999; 1-936.

16. Kovacic R, Somanathan R. Beneficial effects of antioxidants in relation to carcinogens, toxins and various illnesses. In Antioxidants: New Research. Editor. Panglossi HV. Nova Science Publishers Inc., NY 2006; 1.
17. Wenzel E, Somoza V. Metabolism and bioavailability of trans-resveratrol. Mol Nutr Food Res 2005; 49:47281.

18. Wang LX, Heredia A, Song H, Zhang Z, Yu B, Davi $\mathrm{C}$, et al. Resveratrol glucuronides as the metabolites of resveratrol in humans: characterization, synthesis and anti-HIV activity. J Pharm Sci 2004; 93:2448-57.

19. Yu C, Shin YG, Chow A, Li Y, Kosmedar JW, Lee YS, et al. Human, rat and mouse metabolism of resveratrol. Pharm Res 2002; 19:1907-14.

20. Wang D, Hang T, Wu C, Liu W. Identification of the major metabolites of resveratrol in rat urine by HPLCMS/MS. J Chromatogr B Analyt Technol Biomed Life Sci 2005; 829:97-106

21. Wenzel E, Soldo T, Erbersdobler H, Somoza V. Bioactivity and metabolism of trans-resveratrol orally administered to Wister rats. Mol Nutr Food Res 2005. 49:482-94.

22. Muris M, Miksits $M$, Aust $S$, Spatzenegger $M$, Thalhammer T, Szekeres T, et al. Metabolism of resveratrol in breast cancer cell lines: impact of sulfotransferase $1 \mathrm{~A} 1$ expression on cell growth inhibition. Cancer Lett 2008; 261:172-82.

23. Shanker S, Singh G, Srivastava RK. Chemoprevention by resveratrol: molecular mechanisms and therapeutic potential. Front Biosci 2007; 12:4839-54.

24. Pinto MC, García-Barrardo JA, Macías P. Oxidation of resveratrol catalyzed by soybean lipoxygenase. J Agric Food Chem 2003; 51:1653-7. 
25. Losa GA. Resveratrol modulates apoptosis and oxidation in human blood mononuclear cells. Eur J Clin Invest 2003; 33:818-23.

26. Olas B, Wachowicz B, Nowak P, Stochmal A, Oleszek W, Glowacki R, et al. Comparative studies of the antioxidant effects of naturally occurring resveratrol analogue trans-3,3',5,5'-tetrahydroxy-4'-methoxystilbene and resveratrol against oxidation and nitration of biomolecules in blood platelets. Cell Biol Toxicol 2007; 24:331-40.

27. Olas B, Wachowicz B, Majsterek I, Blasiak J. Resveratrol may reduce oxidative stress induced by platinum compounds in human plasma, blood platelets and lymphocytes. Anticancer Drugs 2005; 16:659-65.

28. Hung L-M, Su M-J, Chu W-K, Chiao RC-W, Chan RW-F, Chen RJ-K. The protective effect of resveratrol on ischaemia-reperfusion injuries of rat hearts in correlated with antioxidant efficacy. Brit J Pharmacol 2002; 135:1627-33.

29. Frémont L, Belguendouz L, Delpal S. Antioxidant activity of resveratrol and alcohol-free wine polyphenols related to LDL oxidation and polyunsaturated fatty acids. Life Sci 1999; 64:2511-21.

30. Frankel EN, Waterhouse AL, Kinsella JE. Inhibition of human LDL by resveratrol. Lancet 1993; 341:1103-4.

31. Shakibaei M, John T, Seifarth C, Mobasheri A. Resveratrol inhibited IL-1 beta-induced stimulation of caspase- 3 and cleavage of PARP in human articular chondrocytes in vitro. Ann NY Acad Sci 2007; 1095:554-63.

32. Rubiolo JA, Mithieux G, Vega FV. Resveratrol protects primary rat hepatocytes against oxidative stress damage: activation of the $\mathrm{Nrf} 2$ transcription factor and augmented activities of antioxidant enzymes. Eur J Pharmacol 2008; 591:66-72.

33. Robb EL, Winkelmolen L, Visanji N, Brotchie J, Stuart JA. Dietary resveratrol administration increases MnSOD expression and activity in mouse brain. Biochem Biophys Res Commun 2008; 372:254-9.

34. Kaindl U, Eyberg I, Rohr-Udilov N, Heinzle C, Marian $B$. The dietary antioxidants resveratrol and quercetin protect cells from exogenous pro-oxidative damage. Food Chem Toxicol 2008; 46:1320-6.

35. Goh SSC, Woodman OL, Pepe S, Cao AH, Qin C, Ritchie RH. The red wine antioxidant resveratrol prevents cardiomyocyte injury following ischemia-reperfusion via multiple sites and mechanisms. Antioxid Redox Signal 2007; 9:101-13.

36. Stojanovic S, Sprinz H, Brede O. Efficiency and mechanism of the antioxidant action of trans-resveratrol and its analogues in the radical liposome oxidation. Arch Biochem Biophys 2001; 391:79-89.

37. Szewczuk LM, Lee SH, Blair IA, Penning TM. Viniferin formation by COX-1; evidence for radical intermediates during co-oxidation of resveratrol. J Nat Prod 2005; 68:36-42.

38. Li T, Wang W, Li T. Effect of resveratrol on JAK/ STAT3 signal transduction pathway in leukemia. Zhongguo Shi Yan Xue Ye Za Zhi 2008; 16:772-6.

39. Nicolini G, Rigolio R, Scuteri A, Miloso M, Saccomanno D, Cavaletti G, et al. Effect of trans-resveratrol on signal transduction pathways in paclitaxelinduced apoptosis in human neuroblastoma SH-SY5Y cells. Neurochem Int 2003; 42:419-29.

40. Woo JH, Lim JH, Kim YH, Suh SI, Min DS, Chang JS, et al. Resveratrol inhibits phorbol myristate acetate-induced matrix metalloproteinase-9 expression by inhibiting JNK and PKCdelta signal transduction. Oncogene 2004; 23:1845-53.

41. Kundu Jk, Shin YK, Surh YJ. Resveratrol modulates phorbol ester-induced pro-inflammatory signal transduction pathways in mouse skin in vivo: NFkappaB and AP-1 as prime targets. Biochem Pharmacol 2006; 72:1506-15.

42. Fulda S, Debatin KM. Resveratrol modulation of signal transduction in apoptosis and cell survival: mini-review. Cancer Detec Prev 2006; 30:217-23.
43. Kundu JK, Surh YJ. Cancer chemopreventive and therapeutic potential of resveratrol: mechanistic perspectives. Cancer Lett 2008; 269:243-61.

44. Venkatesan B, Ghosh-Choudhury N, Das F, Mahimainathan L, Kamat A, Kasinath BS, et al. Resveratrol inhibits PDGE receptor mitogenic signaling in mesangial cells: role of PTP1B. FASEB J 2008; 22:3469-82.

45. Harikumar KB, Aggarwal BB. Resveratrol: a multitargeted agent for age-associated chronic diseases. Cell Cycle 2008; 7:1020-35.

46. Cecchinato V, Chiaramonte R, Nizzardo M, Cristofaro B, Basile A, Sherbet GV, et al Resveratrol-induced apoptosis in human T-cell acute lymphoblastic leukaemia MOLT-4 cells. Biochem Pharmacol 2007; 74:1568-74.

47. Filomeni G, Graziani I, Rotilio G. Trans-Resveratro induces apoptosis in human breast cancer cells MCF-7 by the activation of MAP kinases pathways. Genes Nutr 2007; 2:295-305

48. Delmas D, Rébé C, Lacour S, Filomenko R, Athias A, Gambert P, et al. Resveratrol-induced apoptosis is associated with Fas redistribution in the Rafts and the formation of a death-inducing signal complex in colon cancer cells. J Biol Chem 2003; 278:41482-90.

49. Scarlatti F, Sala G, Somenzi G, Signorelli P, Sacchi N, Ghidoni R. Resveratrol induces growth inhibition and apoptosis in metastatic breast cancer cells via de novo ceramide signaling. FASEB J 2003; 17:2339-41.

50. Bhardwaj A, Sethi G, Vardhan-raj S, Bueso-Ramos C, Takada Y, Gaur U, et al. Resveratrol inhibits proliferation, induces apoptosis, and overcomes chemoresistance through downregulation of STAT3 and nuclea factor- $\mathrm{\kappa B}$-regulated antiapoptotic and cell survival gene products in human multiple myeloma cells. Blood 2007; 109:2293-302.

51. She Q-B, Bode AM, Ma W-Y, Chen N-Y, Dong Z Resveratrol-induced activation of $\mathrm{p} 53$ and apoptosis is mediated by extracellular-signal-regulated protein kinases and p38 kinase. Cancer Res 2001; 61:160410.

52. Kotha A, Sekharam M, Cilenti L, Siddiquee K, Khaled A, Zervos AS, et al. Resveratrol inhibits Src and Atat3 signaling and induces the apoptosis of malignant cells containing activated Stat3 protein. Mol Cancer Ther 2006; 5:621-9.

53. Fulda S, Debatin K-M. Resveratrol-mediated sensitization to TRAIL-induced apoptosis depends on death receptor and mitochondrial signaling. Eur J Cancer 2005; 41:786-98.

54. Li Y, Liu J, Liu X, Xing K, Wang Y, Li F, et al Resveratrol-induced cell inhibition of growth and apoptosis in MCF7 human breast cancer cells are associated with modulation of phosphorylated Akt and Caspase-9. Appl Biochem Biotech 2006; 135:181-92.

55. Su J-L, lin M-T, Hong C-C, Chang A-C, Shiah S-G, Wu C-W, et al. Resveratrol induces FasL-related apoptosis through Cdc42 activation of ASK1/JNKdependent signaling pathway in human leukemia HL-60 cells. Carcinogenesis 2005; 26:1-10.

56. Aziz MH, Nihal M, Fu VX, Jarrard DF, Ahmad N. Resveratrol-caused apoptosis of human prostate carcinoma LNCaP cells is mediated via modulation of phosphatidylinositol 3'-kinase/Akt pathway and Bcl-2 family proteins. Mol Cancer Ther 2006; 5:1335-41.

57. Ahmad N, Adhami VM, Afaq F, Feyes DK, Mukhtar H. Resveratrol causes WAF-1/p21-mediated $G_{1}$-phase arrest of cell cycle and induction of apoptosis in human epidermoid carcinoma A431 cells. Clin Cancer Res 2001; 7:1466-73

58. Hwang J-T, Kwak DW, lin SK, Kim HM, Kim YM, Park OJ. Resveratrol induces apoptosis in chemoresistant cancer cells via modulation of AMPK signaling pathway. Ann NY Acad Sci 2007; 1095; 441-8.

59. Kutuk O, Poli G, Basaga H. Resveratrol protects against 4-hydroxynonenal-induced apoptosis by blocking JNK and c-JUN/AP-1 signaling. Toxicol Sci 2006; 90:120-32.
60. Zhang P, Li H, Wu M-L, Chen X-Y, Kong Q-Y, Wang $\mathrm{X}-\mathrm{W}$, et al. c-Myc downregulation: a critical molecular event in resveratrol-induced cell cycle arrest and apoptosis of human medulloblastoma cells. J Neurooncol 2006; 80:123-31.

61. Lin H-Y, Tang H-Y, Keating T, Wu Y-H, Shih A, Hammond D, et al. Resveratrol is pro-apoptotic and thyroid hormone is anti-apoptotic in glioma cells: both actions are intergrin and ERK mediated. Carcinogenesis 2008; 29:62-9.

62. Alkhalf M, El-Mowafy A, Rachid O, Ali A, Al-Attyiah R. Resveratrol-induced apoptosis in human breast cancer cells is mediated primarily through the Caspase3-dependent pathway. Arch Med Res 2008; 39:162-8.

63. Clément M-V, Hirpara JL, Chawdhury S-H, Pervaiz S Chemopreventive agent resveratrol, a natural product derived from grapes, triggers CD95 signaling-dependent apoptosis in human tumor cells. Blood 1998; 92:996-1002.

64. Martín AR, Villegas I, Sánchez-Hidalgo M, de la Lastra CA. The effects of resveratrol, a phytoalexin derived from red wines, on chronic inflammation induced in an experimentally induced colitis model. Brit J Pharmacol 2006; 147:873-85.

65. Cecchinato V, Chiaramonte R, Nizzardo M, Cristofaro B, Basile A, Sherbet GV, et al. Resveratrol-induced apoptosis in human T-cell acute lymphoblastic leukaemia MOLT-4 cells. Biochem Pharmacol 2007; 74:1568-74

66. Kundu JK, Surh Y-J. Molecular basis of chemoprevention by resveratrol: NFKB and AP-1 as potential targets. Mutat Res 2004; 555:65-80.

67. Heiss EH, Schilder YDC, Dirsch VM. Chronic treatment with resveratrol induces redox stress- and ataxia telangiectasia-mutated (ATM)-dependent senescence in p53-positive cancer cells. J Biol Chem 2007; 282:26759-66

68. Yu H, Pan C, Zhao S, Wang Z, Zhang H, Wu W. Resveratrol inhibits tumor necrosis factor- $\alpha$-mediated matrix metalloproteinase-9 expression and invasion of human hepatocellular carcinoma cells. Biomed Pharmacother 2008; 62:366-72.

69. Ivanov V, Partridge MA, Johnson GE, Huang SXL, Zhou H, Hei TK. Resveratrol sensitizes melanomas to TRAIL through modulation of antiapoptotic gene expression. Expt Cell Res 2008; 314:1163-76.

70. Yu L-J, Wu M-L, Li H, Chen X-Y, Wang Q, Sun $\mathrm{Y}$, et al. Inhibition of STAT3 expression and signaling in resveratrol-differentiated medulloblastoma cells. Neoplasia 2008; 10:736-44.

71. Alkhalaf M. Resveratrol-induced growth inhibition in MDA-MB-231 breast cancer cells is associated with mitogen-activated protein kinase signaling and protein translation. Eur J Cancer Prevent 2007; 16:334-41.

72. Roccaro AM, Leleu X, Sacco A, Moreau A-S, Hatjihariss E, Jia X, et al. Resveratrol exerts antiproliferative activity and induces apoptosis in Waldenström's macroglobulinemia. Clin Cancer Res 2008; 14:1849-58.

73. Saiko P, Szakmary A, Jaeger W, Szekeres T. Resveratrol and its analogs: defense against cancer, coronary disease and neurodegenerative maladies or just a fad? Mutat Res 2008; 658:68-94.

74. Tyagi A, Singh RP, Agarwal C, Siriwardane S, Sclafani RA, Agarwal R. Resveratrol causes Cdc2-tyr15 phosphorylation via ATM/ATR-Chk1/2-Cdc25C carcinoma ovcar-3 cells. Carcinogenesis 2005; 26:1978-87.

75. Azios NG, Krishnamoorthy L, Harris M, Cubano LA Cammer M, Dharmawardane SF. Estrogen and resveratrol regulate Rac and Cdc42 signaling to the actin cytoskeleton of metastatic breast cancer cells. Neoplasia 2007; 9:147-58.

76. Fröjdö S, Cozzone D, Vidal H, Pirola L. Resveratrol is a class IA phosphoinositide 3-kinase inhibitor. Biochem J 2007; 406:511-8.

77. Rahman I, Biswas SK, Kirkham PA. Regulation of inflammation and redox signaling by dietary polyphenols. Biochem Pharmacol 2006; 72:1439-52. 
78. Wung BS, Hsu MC, Hsieh CW. Resveratrol suppresses IL-6-induced ICAM-1 gene expression in endothelia cells: effects on the inhibition of STAT3 phosphorylation. Life Sci 2005; 78:389-97.

79. Venkatachalem K, Mummidi S, Cortez DM, Prabhu SD, Valente AJ, Chandrasekar B. Resveratrol inhibits high glucose-induced P13/Akt? ERK-dependent interleukin-17 expression in primary mouse cardiac fibroblast. Am J Physiol Heart Circ Physiol 2008; 294:2078-87.

80. Moon S-O, Kim W, Sung MJ, Lee S, Kang KP, Kim $\mathrm{DH}$, et al. Resveratrol suppresses tumor necrosis factor$\alpha$-induced fractalkine expression in endothelial cells. Mol Pharmacol 2006; 70:112-9.

81. Csaki C, Keshishzadeh N, Fischer K, Shakibaei M. Regulation of inflammation signaling by resveratrol in human chondrocytes in vitro. Biochem Pharmacol 2008; 75:677-87.

82. Kundu JK, Shin YK, Surh Y-J. Resveratrol modulates phorbol ester induced pro-inflammatory signal transduction pathways in mouse skin in vivo: NFKB and AP1 as prime targets. Biochem Pharmacol 2006; 72:1506-15.

83. Youn HS, Lee JY, Fitzgerald KA, Young HA, Akira S. Specific inhibition of MyD88-independent signaling pathways of TLR3 and TLR4 by resveratrol: molecular targets are TBK1 and RIP1 in TRIF complex. J Immunol 2005; 175:3339-46.

84. Hwang J-T, Kwon DY, Park OJ, Kim MS. Resveratrol protects ROS-induced cell death by activating AMPK in H9c2 cardiac muscle cells. Genes Nutr 2008; 2:323-6.

85. Csiszar A, Smith K, Labinskyy N, Orosz Z, Rivera A, Ungvsri Z. Resveratrol attenuates TNF $\alpha$-induced activation of coronary arterial endothelial cells: role of NFKB inhibition. Am J Physiol Heart Circ Physiol 2006; 291:1694-9.

86. Huang Z, Wang C, Wei L, Wang J, fan Y, Wang L, et al. Resveratrol inhibits EMMMPRIN expression via P38 and ERK1/2 pathways in PMA-induced THP-1 cells. Biochem Biophys Res Commun 2008; 374:517-21.

87. Das S, Tosaki A, Bagchi D, Maulik N, Das DK. Potentiation of a survival signal in the ischemic heart by resveratrol through p38 mitogen-activated protein kinase/mitogen-and stress-activated protein kinase 1/ cAMP response element-binding protein signaling. J Pharmacol Expt Therapeut 2006; 317:980-8.

88. Das S, Cordis GA, Maulik N, Das DK. Pharmacological preconditioning with resveratrol: role of CREBdependent $\mathrm{Bcl}-2$ signaling via adenosine $\mathrm{A}_{3}$ receptor activation. Am J Physiol Heart Circ Physiol 2005; 288:328-35.

89. Das S, Fraga CG, Das DK. Cardioprotective effect of resveratrol via HO-1 expression involves p38 map kinase and P13-kinase signaling, but does not involve NFKB. Free Rad Res 2006; 40:1066-75.

90. Haider UGB, Sorescu D, Griendling KK, Vollmar AM, Dirsch VM. Resveratrol suppresses angiotensin II-induced Akt/proten kinase B and p70 S6 kinase phosphorylation and subsequent hypertrophy in rat aortic smooth muscle cells. Mol Pharmacol 2002; 62:772-7

91. Chen C-Y, Jang J-H, Li M-H, Surh Y-J. Resveratrol upregulates heme oxygenase-1 expression via activation of NF-E2-related factor 2 in PC12 cells. Biochem Biophys Res Commun 2005; 331:993-1000.

92. King RE, Kent KD, Bomser JA. Resveratrol reduces oxidation and proliferation of human epithelial cells via extracellular signal-regulated kinase inhibition. Chem Biol Interact 2005; 151:243-9.

93. Breen DM, Sanil T, Giacca A, Tsiani E. Stimulation of muscle cell glucose uptake by resveratrol through sirtuins and AMPK. Biochem Biophys Res Commun 2008; 374:117-22
94. Kode A, Rajendrasozhan S, Caito S, Yang S-R, Megson IL, Rahman I. Resveratrol induces glutathione synthesis by activation of $\mathrm{Nrf} 2$ and protects against cigarette smoke-mediated oxidative stress in human lung epithelial cells. Am J Physiol Lung Cell Mol Physiol 2008; 294:478-88.

95. Ajmo JM, Liang X, Rogers CQ, Pennock B, You M Resveratrol alleviates alcoholic fatty liver in mice. Am J Gastroint Liver Physiol 2008; 295:833-42.

96. Stefani M, Markus MA, Lin RCY, Pinese M, Dawes IW, Morris BJ. The effect of resveratrol on cell model of human aging. Ann NY Acad Sci 2007; 1114:407-18.

97. Shakibaei M, John T, Seifarth C, Mobasheri A. Resveratrol inhibits IL- $1 \beta$-induced stimulation of caspase- 3 and cleavage of PARP in human articular chondrocytes in vitro. Ann NY Acad Sci 2007; 1095:554-63.

98. Godichaud S, Si-Tayeb K, Augé N, Desmouliére A Balabaud C, Payrastre B, et al. The grape-derived polyphenol resveratrol differently affects epidermal and plateletderived growth factor signaling in human liver myofibroblasts. Int J Biochem Cell Biol 2006; 38:629-37.

99. Leiro J, Arranz JA, Fraiz N, Sanmartin ML, Quezada E, Orallo F. Effect of cis-resveratrol on genes involved in nuclear factor kappaB signaling. Int Immunopharmacol 2005; 5:393-406

100. Poolman TM, Ng LL, Farmer PB, Manson MM. Inhibition of the respiratory burst by resveratrol in human monocytes: correlation with inhibition of P13K signaling. Free Radic Biol Med 2005; 39:118-32.

101. Dasgupta B, Milbrandt J. Resveratrol stimulates AMP kinase activity in neurons. PNAS 2007; 104:7217-22.

102. Klinge CM, Blankenship KA, Risingert KE, Bhatnaga $S$, Noisin EL, Sumanasekara WK, et al. Resveratro and estradiol rapidly activate MAPK signaling through estrogen receptors $\alpha$ and $\beta$ in endothelial cells. J Biol Chem 2005; 280:7460-8.

103. Forman HG, Cadenas E. Oxidative Stress and Signal Transduction, Chapman and Hall, New York 1997; $1-475$.

104. Hancock GT. Cell Signaling. Oxford University Press, New York 2005; 1-296.

105. Demple B. Oxidative stress and signal transduction. In: Handbook of Cell Signaling. Bradshaw RA, Dennis EA, eds., Academic Press, Boston 2004; 78:293-307.

106. Kovacic P, Pozos RS. Cell signaling (mechanism and reproductive toxicity): redox chains, electrons, relays, conduit, electrochemistry and other medical implications. Birth Defects Res Part C 2006; 28:333-44.

107. Kovacic P. Protein electron transfer (mechanism and reproductive toxicity): iminium, hydrogen bonding, homoconjugation, amino acid side chains and cell signaling. Birth Defects Res 2007; 81:51-64.

108. Kovacic P, Pozos RS, Draskovich CD. Unifying electrostatic mechanism for receptor-ligand activity. J Recep Signal Transduct 2007; 27:411-32.

109. Kovacic P, Draskovich CD, Pozos RS. Unifying electrostatic mechanism for phosphates and sulfates in cell signaling. J Recept Signal Transduct 2007; 27:433-43.

110. Kovacic P. Unifying electrostatic mechanism for meta cations in receptors and cell signaling. J Recept Signal Transduct 2008; 28:153-62.

111. Le Corre L, Fustier P, Chalabi N, Bignon YJ, BernardGallon D. Effects of resveratrol on expression of pane of genes interacting with the BRCA1 oncosuppressor in human breast cancer cell lines. Clin Chim Acta 2004; 344:115-21.

112. Hambrock A, Franz CBDO, Hiller S, Grenz A, Ackerman S, Schulze DU, et al. Resveratrol binds to the sulfonylurea receptor (SUR) and induces apoptosis in a SUR subtype-specific manner. J Biol Chem 2007; 282:3347-56.

113. Gao S, Liu GZ, Wang Z. Modulation of androgen receptor-dependent transcription by resveratro and genistein in prostate cancer cells. Prostate 2004; 59:214-25.
114. Shi WF, Leong M, Cho E, Farrell J, Chen HC, Tian J, Zhang D. Repressive effects of resveratrol on androgen receptor transcriptional activity. PLOS One 2009; 4:7398.

115. Harada N, Murata Y, Yamji R, Miura T, Inui H, Nakano Y. Resveratrol downregulates the androgen receptor at the post-translational level in prostate cancer cells. J Nutr Sci Vitaminol 2007; 53:556-60.

116. Mitchell SH, Zhu, Young CY. Resveratrol inhibits the expression and function of the androgen receptor in LNCaP prostate cancer cells. Cancer Res 1999; 59:5892-5.

117. Casper RF, Quesne M, Rogers IM, Shirota T, Jolivet A, Milgrom E, Savouret J-F. Resveratrol has antagonist activity on the aryl hydrocarbon receptor: implication for prevention of dioxin toxicity. Mol Pharmacol 1999; 56:784-90.

118. Jakab M, lach S, Bacová Z, Langelüddecke C, Strbák $\mathrm{V}$, Schmidt S, et al. Resveratrol inhibits electrical activity and insulin release from insulinoma cells by block of voltage-gated $\mathrm{Ca}^{+}$channels and swelling-dependent $\mathrm{Cl}^{-}$currents. Cell Physiol Biochem 2008; 22:567-78.

119. Wang R, Xiao L, Ma HJ, Zhang LH, He RR, Wu YM, et al. Resveratrol inhibits electrical activity of paraventricular nucleus neurons in rat hypothalamic slices. Acta Physologica Sinica 2008; 60:279-83.

120. Li M, Wang QS, Chen Y, Wang ZM, Liu Z, Guo SM, et al. Resveratrol inhibits the electrical activity of subfornical organ neurons in rat. Acta Physiologica Sinica 2005; 57:523-8.

121. Buluc M, Ayaz M, Turan B, Demirel-Yilmaz E. Resveratrol-induced depression of the mechanical and electrical activities of the rat heart is reversed by glyburide: evidence for possible K(ATO) channels activation. Arch Pharm Res 2007; 30:603-7.

122. Kovacic P, Hall ME. Bioelectrochemistry, reactive oxygen species, receptor and cell signaling: How interrelated? J Recept Signal Tranduct 2010; 30:1-9.

123. Markus MA, Morris BJ. Resveratrol in prevention and treatment of common conditions of aging. Clin Interv Aging 2008; 3:331-9.

124. Barger JL, Kayo T, Vann JM, Arias EB, Wang J, Hacker TA, et al. A low dose of dietary resveratrol partially mimics caloric restriction and retards aging parameters in mice. PLoS One 2008; 3:2264.

125. Baxter RA. Anti-aging properties of resveratrol: review and report of potent new antioxidant skin care formulation. J Cosmet Dermatol 2008; 7:2-7.

126. Valenzano DR, Cellerino A. Resveratrol and the pharmacology of aging: a new vertebtrate model to validate an old molecule. Cell Cycle 2006; 5:1027-32.

127. Labinskyy N, Csiszar A, Veress G, Stef G, Pacher P, Oroszi $\mathrm{G}$, et al. Vascular dysfunction in aging: potential effects of resveratrol, an anti-inflammatory phytoestrogen. Curr Med Chem 2006; 13:989-96.

128. Jnutson MD, Leeuwenburgh C. Resveratrol and novel potent activators of SIRT1: effects on aging and agerelated diseases. Nutr Rev 2008; 66:591-6.

129. Sengottuvelan M, Viswanathan P, Nalini N Chemopreventive effect of trans-resveratrol-1 phytoalexin against colonic aberrant crypt foci and cell proliferation in 1,2-dimethylhydrazine induced colon carcinogenesis. Carcinogenesis 2006; 27:1038-46.

130. Athar M, Back JH, Tang X, Kim KH, Kopelovich L, Bickers DR, et al. Resveratrol: a review of preclinical studies for human cancer prevention. Toxicol Appl Pharmacol 2007; 224:274-83.

131. Chan W-H. Effect of resveratrol on high glucoseinduced stress in human leukemia K562 cells. J Cellular Biochem 2005; 94:1267-79.

132. Jang M, Pezzuto JM. Effect of resveratrol on 12-O-tetradecanolphenol-13-acetate-induced oxidative events and gene expression in mouse skin. Cancer Lett 1998; 134:81-9.

133. Kozuki Y, Miura Y, Yagasaki K. Resveratrol suppresses hepatoma cell invasion independently of its antiproliferation action. Cancer Lett 2001; 167:151-6. 
134. Le Corre L, Chalabi N, Delort L, Bignon Y-J, BernardGallon DJ. Resveratrol and breast cancer chemoprevention: molecular mechanisms. Mol Nutr Food Res 2005; 49:462-71.

135. Bhat KPL, Pezzuto JM. Cancer chemopreventive activity of resveratrol. Ann NY Acad Sci 2002; 957:21029.

136. Ratan HL, Steward WP, Gescher AJ, Mellon JK. Resveratrol-a prostate cancer chemopreventive agent? Urologic Oncolo 2002; 7:223-7.

137. Sun W, Wang W, Kim J, Keng P, Yang S, Zhang H, et al. Anti-cancer effect of resveratrol is associated with induction of apoptosis via a mitochondrial pathway alignment. Adv Exp Med Biol 2008; 614:179-86.

138. Signorelli P, Ghidoni R. Resveratrol as an anticancer nutrient: molecular basis, open questions and promises. J Nutr Biochem 2005; 16:449-66.

139. Joe AK, Liu H, Suzui M, Vural ME, Xiao D, Weinstein B. Resveratrol induces growth inhibition, S-phase arrest, apoptosis, and cell changes in biomarker expression in several human cancer cell lines. Clin Cancer Res 2002; 8:893-903.

140. Shanker S, Siddiqui I, Srivastava RK. Molecular mechanisms of resveratrol (3,4,5-trihydroxy-trans-stilbene) and its interaction with TNF-related apoptosis inducing ligand (TRAIL) in androgen-insensitive prostate cancer cells. Mol Cell Biochem 2007; 304:273-85.

141. Puissant A, Grosso S, Jacquel A, Belhacene N, Colosetti P, Cassuto J-P, et al. Imatinib mesylate-resistant human chronic myelogenous leukemia cell line exhibit high sensitivity to the phytoalexin resveratrol. FASEB J 2008; 22:1894-904.

142. Filomeni G, Graziani I, Rorilio G, Ciriolo MR. transResveratrol induces apoptosis in human breast cancer cells MCF-7 by the activation of MAP kinases pathways. Genes Nutr 2007; 2:295-305.

143. Tang H-Y, Shih A, Cao J, Davis FB, Lin H-Y. Resveratrol-induced cyclooxygenase-2-facilitates p53dependent apoptosis in human breast cancer cells. Mol Cancer Ther 2006; 5:2034-42.

144. Mohan J, Gandhi AA, Bhavya AV, Rashmi R, Karunagaran D, Indu R, et al. Caspase-2 triggers BaxBak-dependent and -independent cell death in colon cancer cells treated with resveratrol. J Biol Chem 2006; 281:17599-611.

145. Atten MJ, Godoy-Romero E, Attar BM, Milson T, Zopel M, Holian O. Resveratrol regulates cellular PKC $\alpha$ and $\delta$ to inhibit growth and induces apoptosis in gastric cancer cells. Invest New Drugs 2005; 23:111-9.

146. Shih A, Davis FB, Lin H-Y, Davis PJ. Resveratrol induces apoptosis in thyroid cancer cell lines via a MAPK- and p53-dependent mechanism. J Clin Endocrinol Metabol 2002; 87:1223-32.

147. Ahmad KA, Clement M-V, Hanif IM, Pervez S. Resveratrol inhibits drug-induced apoptosis in human leukemia cells by creating an intracellular milieu nonpermissive for death execution. Cancer Res 2004; 64:1452-9.

148. Johnson GE, Ivonov VN, Hei TK. Radiosensitization of melanoma cells through combined inhibition of protein regulators of cell survival. Int J Programmed Cell Death 2008; 13:790-802.

149. Shao J, Li X, Lu X, jiang C, Hu Y, Li Q, et al. Enhanced growth inhibition effect resveratrol incorporated into biodegradable nanoparticles against glioma cells is mediated by the induction of intracellualr reactive oxygen species levels. Colloids Surf B; Biointerfaces 2009; 72:40-7.

150. Stewart JR, O'Brian CA. Resveratrol antagonized EGFR-dependent Erk1/2 activation in human androgen-independent prostate cancer cells with associated isozyme-selective PKC $\alpha$ inhibition. Invest New Drugs 2004; 22:107-17.

151. Golkar L, Ding X-Z, Ujiki MB, Salabat MR, Kelly DL, Scholtens D, et al. Resveratrol inhibits pancreatic cancer cell proliferation through transcriptional induction of macrophage inhibitory cytokine-1. J Surg Res 2007; 138:163-9.
152. Harper CE, Patel BB, Wang J, Arabshahi A, Eltoum IA, Lamartiniere A. Resveratrol suppresses prostate cance progression in transgenic mice. Carcinogenesis 2007; 28:1946-53.

153. Hudson TS, Hartle DK, Hursting SD, Nunez NP, Wang TTY, Young HA, et al. Inhibition of prostate cancer growth by muscadine grape skin extract and resveratrol through distinct mechanisms. Cancer Res 2007; 67:8396-405.

154. Benitez DA, Pozo-Guisado E, Clementi M, Castellón E, Fernandez-Salguero PM. Non-genomic action of resveratrol on androgen and oestrogen receptors in prostate cancer: modulation of the phosphoinosotide 3-kinase pathway. Brit J Cancer 2007; 96:1595-604.

155. Aggarwal BB, Bhardwaj A, Aggarwal RS, Seeram NP, Shishodia S, Takada Y. Role of resveratrol in prevention and therapy of cancer: preclinical and clinical studies. Anticancer Res 2004; 24:2783-840.

156. Lin HY, Sun M, Tang HY, Simone TM, Wu YH, Grandis JR, et al. Resveratrol causes COX-2-and p53dependent apoptosis in head and neck squamous cell cancer cells. J Cell Biochem 2008; 104:2131-42.

157. Hope C, Planutis K, Planutiene M, Moyer MP, Johal $\mathrm{KS}$, Woo J, et al. Low concentration of resveratro inhibit Wnt signal throughput in colon-derived cells: implications for colon cancer prevention. Mol Nutr Food Res 2008; 52:52-61.

158. Gill C, Walsh SE, Morrissey C, Fitzpatrick JM, Watson RW. Resveratrol sensitizes androgen independent prostate cancer cells to death-receptor mediated apoptosis through multiple mechanisms. Prostate 2007; 67:1641-53.

159. Kovacic P. Electron transfer mechanism for regulatory action of nitic oxide. Bioelectrochem Bioenerg 1996 39:155-9.

160. Holian O, Wahid S, Atten MJ, Attar BM. Inhibition of gastric cancer cell proliferation by resveratrol; role of nitric oxide. Am J Physiol Gastrointest Liver Physiol 2002; 282:809-16.

161. Gusman J, Malonne H, Atassi G. A reappraisal of the potential chemopreventive and chemotherapeutic properties of resveratrol. Carcinogenesis 2001; 22:1111-7.

162. Stewart JR, Artime MC, O'Brian CA. Resveratrol: a candidate nutritional substance for prostate cancer prevention. J Nutr 2003; 133:2440-3.

163. Zhang Q, Tang X, Lu QY, Zhang ZF, Brown J, Le AD. Resveratrol inhibits hypoxia-induced accumulation of hypoxia-inducible factor- $1 \alpha$ and VEGF expression in human tongue squamous cell carcinoma and hepatoma cells. Mol Cancer Ther 2005; 4:1465-74.

164. Wolter F, Ulrich S, Stein J. Molecular mechanisms of the chemopreventive effects of resveratrol and its analogs in colorectal cancer: key role of polyamines? J Nutr 2004; 134:3219-22.

165. Wang TTY, Hudson TS, Wang T-C, Remsberg CM, Davis NM, Takahashi Y, et al. Differential effects of resveratrol on androgen-responsive $\mathrm{LNCaP}$ human protate cancer cells in vitro and in vivo. Carcinogenesis 2008; 29:2001-10.

166. Tang F-Y, Chiang E-PI, Sun Y-C. Resveratrol inhibits heregulin- $\beta 1$-mediated matrix metalloproteinase- 9 expression and cell invasion in human breast cancer cells. J Nutr Biochem 2008; 19:287-94.

167. Scarlatti F, Maffei R, Beau I, Codogno P, Ghidoni R. Role of non-canonical Beclin 1-independent autophagy in cell death induced by resveratrol in human breast cancer cells. Cell Death Differentiation 2008; 15:1318 29.

168. Nakagawa H, Kiyozuka Y, Uemura Y, Senzaki H, Shikata N, Hioki K, et al. Resveratrol inhibits human breast cancer cell growth and may mitigate the effect of linoleic acid, a potent breast cancer cell stimulator. J Cancer Res Clin Oncol 2001; 127:258-64.

169. Melilo G. Targeting hypoxia cell signaling for cancer therapy. Cancer Metastasis Rev 2007; 26:341-52.
170. Trincheri NF, Nicotra G, Follo C, Castino R, Isidoro C. Resveratrol induces cell death in colorectal cancer cells by novel pathway involving lysosomal cathepsin D. Carcinogenesis 2007; 28:922-31.

171. Kuwajerwala N, Cifuentes E, Gautam S, Menon M, Barrack ER, Reddy GPV. Resveratrol induces prostate cancer cell entry into $S$ phase and inhibits DNA synthesis. Cancer Res 2002; 62:2488-92.

172. van Ginkel PR, Darjatmoko SR, Sareen D, Subramanian L, Bhattacharya S, Lindstrom MJ, et al. Resveratrol inhibits uveal melanoma tumor growth via early mitochondrial dysfunction. Invest Ophthalmol Vis Sci 2008; 49:1299-306.

173. Wolter F, Akoglu B, Clausnitzer A, Stein J. Downregulation of the cyclin D1/Cdk4 complex occurs during resveratrol-induced cell cycle arrest in colon cancer cell lines. J Nutr 2001; 131:2197-203.

174. Baur JA, Sinclair DA. Therapeutic potential of resveratrol: the in vivo evidence. Nature Rev Drug Disc 2006; 5:493-506.

175. Chao H-H, Juan S-H, Liu J-C, Yang H-Y, Yang E, Cheng $\mathrm{T}-\mathrm{H}$, et al. Resveratrol inhibits angiotensin II-induced endothelin-1 gene expression and subsequent proliferation in rat aortic smooth muscle cells Eur J Pharmacol 2005; 515:1-9.

176. Labinskyy N, Csiszar A, Veress G, Stef G, Pacher P, Oroszi G, et al. Vascular dysfunction in aging: potentia effects of resveratrol, an anti-inflammatory phytoestrogen. Curr Med Chem 2006; 13:989-96.

177. Hung L-M, Chen J-K, Huang S-S, Lee R-S, Su M-J. Cardioprotective effect of resveratrol, a natural antioxidant derived from grapes. Cardiovascular Res 2000; 47:549-55

178. Sato M, Ray PS, Maulik G, Maulik N, Engelman RM, Bertelli AAE, et al. Myocardial protection with red wine extract. J Cardiovascular Pharmacol 2000; 35:263-8.

179. Shigematsu S, Ishida S, Hara M, Takahashi N, Yoshimatsu H, Sakata T, et al. Resveratrol, a red wine constituent polyphenol, prevents superoxide-dependent imflammatory response induced by ischemia/ reperfusion, platelet-activating factor, or oxidants. Free Radic Biol Med 2003; 34:810-7.

180. Delms D, Jannin B, Latruffe N. Resveratrol: preventing properties against vascular alterations and aging. $\mathrm{Mol}$ Nutr Food Res 2005; 49:377-95.

181. Floreani M, Napoli E, Quintieri L, Palatini P. Oral administration of trans-resveratrol to guinea pigs increases cardiac DT-diaphorase and catalase activities, and protects isolated atria from menadione toxicity. Life Sci 2003; 72:2741-51.

182. Rotonado S, Rajtar G, Manarini S, Celardo A, Rotillo D, de Gaetano G, et al. Effect of trans-resveratrol, natural polyphenolic compound, on human polymorphonuclear leukocyte function. Brit J Pharmacol 1998; 123:1691-9.

183. Tedesco I, Russo M, Russo P, Iacomino G, Russo GL, Carraturo A, et al. Antioxidant effect of red wine polyphenols on red blood cells. J Nutr Biochem 2000; 11:114-9.

184. Ungvari Z, Orosz Z, Rivera A, Labinskyy N, Xiangmin $Z$, Olson S, et al. Resveratrol increases vascular oxidative stress resistance. Am J Physiol Heart Circ Physiol 2007; 292:2417-24

185. Li Y, Cao Z, Zhu H. Upregulation of endogenous antioxidants and phase 2 enzymes by the red wine polyphenol, resveratrol in cultured aortic smooth muscle cells leads to cytoprotection against oxidative and electrophilic stress. Pharmacol Res 2006; 53:6-15.

186. Olas B, Wachowicz B. Resveratrol and vitamin C antioxidants in blood platelets. Thrombosis Res 2002; 106:143-4.

187. Olas B, Wachowicz B, Saluk-Juszczak J, Zielinki T, Kaca W, Buczynski A. Antioxidant activity of resveratrol in endotoxin-stimulated blood platelets. Cell Biol Toxicol 2001; 17:117-25. 
188. Fulda S, Debatin KM. Resveratrol modulation of signal transduction in apoptosis and cell survival: mini-review. Cancer Detec Prev 2006; 30:217-23.

189. Olas B, Zbikowska HM, Wachowicz B, Krajewski T, Buczynski A, Magnuszewska A. Inhibitory effect of resveratrol on free radical generation in blood platelets. Acta Biochem Pol 1999; 46:961-6.

190. Olas B, Wachowicz B. Resveratrol, a phenolic antioxidant with effects on blood platelet function. Platelets 2005; 16:251-60.

191. Zhuang H, Kim Y-S, Koehler RC, Doré S. Potential mechanism by which resveratrol, a red wine constituent, protects neurons. Ann NY Acad Sci 2003; 993:276-86.

192. Bastianetto S, Quirion R. Natural extracts as possible protective agents of brain aging. Neurobiol Aging 2002; 23:891-7.

193. Mokni M, Elkahoui S, Limam F, Amri M, Aouani E. Effect of resveratrol on antioxidant enzyme activities in the brain of healthy rat. Neurochem Res 2007; 32:981-7

194. Anekonda TS. Resveratrol-a boon for treating Alzheimer's disease? Brain Res Rev 2006; 52:316-26.

195. Jang J-H, Surh Y-J. Protective effect of resveratrol on $\beta$-amyloid-induced oxidative PC12 cell death. Free Radic Biol Med 2003; 34:1100-10.

196. Rossi L, Mazzitelli S, Arcello M, Capo CR, Rotillo G. Benefits from dietary polyphenols for brain aging and Alzheimer's disease. Neurochem Res 2008; 33:2390400.

197. Sun AY, Simonyi A, Sun GY. The "French paradox" and beyond: neuroprotective effects of polyphenols. Free Radic Biol Med 2002; 32:314-8.

198. Pallás M, Casadesús G, Smith MA, Coto-Montes A, Pelegri C, Vilaplana J, et al. Resveratrol and neurodegenerative diseases: activation of SIRT1 as the potential pathway towards neroprotection. Curr Neurovasc Res 2009; 6:70-81.

199. Rocha-González HI, Ambriz-Tututi M, Granados-Soto V. Resveratrol: a natural compound with pharmacological potential in neurodegenerative diseases. CNS Neurosci Ther 2008; 14:234-47.

200. Ates O, Cayli S, Altinoz E, Gurses I, Yucel N, Sener M, et al. Neuroprotection by resveratrol against traumatic brain injury in rats. Mol Cell Biochem 2007; 294:137-44.

201. Sönmez U, Sönmez A, Erbil G, Tekmen I, Baykara B. Neuroprotective effects of resveratrol against traumatic brain injury in immature rats. Neurosci Lett 2007; 420:133-7.

202. Wang Q, Xu J, Rottinghaus GE, Simonyi A, Lubahn D, Sun GY, et al. Resveratrol protects against global cerebral ischemic injury in gerbils. Brain Res 2002; 958:439-47.

203. Yousuf S, Atif F, Ahmad M, Hoda N, Ishrat T, Khan $\mathrm{B}$, et al. Resveratrol exerts its neuroprotective effect by modulating mitiochondrial dysfunction and associated cell death during cerebral ischemia. Brain Res 2009; 1250:242-53.

204. Ates O, Cayli SR, Yucel N, Altinoz E, Kocak A, Durak $\mathrm{MA}$, et al. Central nervous system protection by resveratrol in streptozotocin-induced diabetic rats. J Clin Nerurosci 2007; 14:256-60.

205. Kumar A, Kaundal RK, Iyer S, Sharma SS. Effects of resveratrol on nerve functions, oxidative stress and DNA fragmentation in experimental diabetic neuropathy. Life Sci 2007; 80:1236-44.

206. Lu KT, Ko MC, Chen BY, Huang JC, Hsieh JC, Lee $\mathrm{MC}$, et al. Neuroprotective effects of resveratrol on MPTP-induced neuron loss mediated by free radical scavenging. J Agric Food Chem 2008; 56:6910-3.

207. Blanchet J, Longpré F, Bureau G, Morissette M, DiPaolo T, Bronchti G, et al. Resveratrol, a red wine polyphenol, protects dopaminergic neurons in MPTP-treated mice. Prog Neuropsychopharmacol Biol Psychiatry 2008; 32:1243-50.
208. Gupta YK, Briyal S, Chaudhary G. Protective effect of trans-resveratrol against kainic acid-induced seizures and oxidative stress in rats. Pharmacol Biochem Behav 2002; 71:245-9.

209. Bastianetto S, Zheng W-H, Quirion R. Neuroprotective abilities of resveratrol and other red wine constituents against nitric oxide-related toxicity in cultured hippocampal neurons. Brit J Pharmacol 2000; 131:711 20.

210. Tsai SK, Hung LM, Fu YT, Cheng H, Nien MW, Liu HY, et al. Resveratrol neuroprotective effects during focal cerebral ischemia injury via nitric oxide mechanism in rats. J Vasc Surg 2007; 46:346-53.

211. Donnelly LE, Newton R, Kennedy GE, Fenwick PS, Leung RH, Ito K, et al. Anti-inflammatory effects of resveratrol in lung epithelial cells: molecular mechanism. Am J Physiol Lung Cell Mol Physiol 2004; 287:774-83.

212. Wu CT, Yu HP, Chung CY, Lau YT, Liao SK Attenuation of lung inflammation and pro-inflammatory cytokine production by resveratrol following trauma-hemorrhage. Chin J Physiol 2008; 51:363-8.

213. de la Lastra CA, Villegas I. Resveratrol as an antiinflammatory and anti-aging agent: mechanisms and clinical implications. Mol Nutr Food Res 2005; 49:405-30.

214. Meng Y, Ma QY, Kou XP, Xu J. Effect of resveratro on activation of nuclear factor kappaB and inflammatory factors in rat model of acute pancreatitis. World J Gastroenterol 2005; 11:525-8.

215. Shiggematsu S, Ishida S, Hara M, Takahashi N, Yoshimatsu H, Sakata T, et al. Resveratrol, a red wine constituent polyphenol, prevents superoxide-dependent inflammatory response induced by ischemia/ reperfusion, platelet-activating factor, or oxidants. Free Radic Biol Med 2003; 34:810-7.

216. Das S, Falchi M, Bertelli A, Maulik N, Das DK Attenuation of ischemia/reperfusion injury in rats by the anti-inflammatory action of resveratrol. ArzneimittelForchung 2006; 56:700-6.

217. Khanna D, Sethi G, Ahn KS, Pandey MK, Kunnumakkara AB, Sung B, et al. Natural products as gold mine for the arthritis treatment. Curr Opin Pharmacol 2007; 7:344-51.

218. Csaki C, Keshishzaden N, Fischer K, Shakibaei M. Regulation of inflammation signaling by resveratrol in human chondrocytes in vitro. Biochem Pharmacol 2008; 75:677-87.

219. Elmali N, Baysal O, Esenkaya I, Mizrak B. Effects of resveratrol in inflammatory arthritis. Inflammation 2007; 30:1-6.

220. Upadhyay G, Singh AK, Kumar A, Prakash O, Singh MP. Resveratrol modulates pyrogallol-induced changes in hepatic toxicity markers, xenobiotic metabolizing enzymes and oxidative stress. Eur J Pharmacol 2008; 596:146-52.

221. Rocha KK, Souza GA, Ebaid GX, Seiva FR, Cataneo AC, Novelli EL. Resveratrol toxicity: effects on risk factors for atherosclerosis and hepatic oxidative stress in standard and high-fat diets. Food Chem Toxicol 2009; 47:1362-7.

222. Bishayee A, Dhir N. Resveratrol-mediated chemoprevention of diethynitrosamine-initiated hepatocarcinogenesis: inhibition of cell proliferation and induction of apoptosis. Chem Biol Interact 2009; 179:131-44.

223. Raal A, Pokk P, Arend A, Aunapuu M, Jōgi J, Okva $\mathrm{K}$, et al. Trans-resveratrol alone and hydroxystilbenes of rhubarb (Rhenum rhaponticum L.) root reduce live damage induced by chronic ethanol administration: a comparative study in mice. Phytother Res 2009; 23:525-32.

224. Kasdallah-Grissa A, Mornagui B, Aouani E, Hammam M, May ME, Gharbi N, et al. Resveratrol, a red wine polyphenol, attenuates ethanol-induced oxidative stress in rat liver. Life Sci 2007; 80:1033-9.
225. Cadenas S, Barja G. Resveratrol, melatonin, vitamin E and $\mathrm{PBN}$ protect against renal oxidative DNA damage induced by the kidney carcinogen $\mathrm{KBrO}_{3}$. Free Radic Biol Med 1999; 26:1531-7.

226. Giovannini L, Migliori M, Longoni BM, Das DK, Bertelli AAE, Panichi V, et al. Resveratrol, a polyphenol found in wine, reduces ischemia reperfusion injury in rat kidneys. J Cardiovascul Pharmacol 2001; 37:262 70 .

227. Sener G, Tugrepe H, Yüksel M, Çetinel S, Gedik N, Yegen C. Resveratrol improves ischemia/reperfusioninduced oxidative renal injury in rats. Arch Med Res 2006; 37:822-9.

228. Rodrigo R, Rivera G. Renal damage mediated by oxidative stress: a hypothesis of protective effects of red wine. Free Radic Biol Med 2002; 33:409-22.

229. Rodrigo R, Bosco C. Oxidative stress and protective effects of polyphenols: comparative studies in human and rodent kidney. A review. Comparat Biochem Physiol Part C 2006; 142:317-27.

230. Sgambato A, Ardito R, Faraglia B, Boninsegna A, Wolf FI, Cittadini A. Resveratrol, a natural phenolic compound, inhibits cell proliferation and prevents oxidative DNA damage. Mutat Res 2001; 496:171-80.

231. Burkhardt S, Reiter RJ, Tan D-X, Hardeland R, Cabrera J, Karbownik M. DNA oxidatively damaged by chromium (III) and $\mathrm{H}_{2} \mathrm{O}_{2}$ is protected by the antioxidants melatonin, $\mathrm{N}^{1}$-acetyl- $\mathrm{N}^{2}$-formyl-5-methoxyynuramine, resveratrol and uric acid. Int J Biochem Cell Biol 2001; 33:775-83

232. Quincozes-Santos A, Andreazza AC, Nardin P, Funchal C, Gonçalves C-A, Gottfried C. Resveratrol attenuates oxidative-induced DNA damage in C6 Glioma cells. Neuro Toxicol 2007; 28:886-91.

233. Russo A, Palumbo M, Aliano C, Lempereur L, Scoto G, Renis M. Red wine micronutrients as protective agents in Alzheimer-like induced insult. Life Sci 2003; 72:2369-79.

234. Leiro J, Arranz JA, Fraiz N, Sanmartin ML, Quezada E, Orallo F. Effect of cis-resveratrol on genes involved in nuclear factor kappaB signaling. Int Immunopharmacol 2005; 5:393-406.

235. Oike H, Kobori M. Resveratrol regulates circadian clock genes in Rat-1 fibroblast cells. Biosci Biotechnol Biochem 2008; 72:3038-40.

236. Zini R, Morin C, Bertelli A, Bertelli AAE, Tillement J-P. Resveratrol-induced limitation of dysfunction of mitochondria isolated from rat brain in an anoxiareoxygenation model. Life Sci 2002; 71:3091-108.

237. Lee M, Kim S, Kwon OK, Oh SR, Lee HK, Ahn K. Anti-inflammatory and anti-asthmatic effects of resveratrol, a polyphenolic stilbene, in mouse model of allergic asthma. Int Immunopharmacol 2009; 9:41824.

238. Kasdallah-Grissa A, Mornagui B, Aouani E, Hammam M, Gharbi N, Kamoun A, et al. Protective effect of resveratrol on ethanol-induced lipid peroxidation in rats. Alcohol Alcoholism 2006; 41:236-9.

239. Simonni G, Pignone A, Generini S, Falcini F, Cerinic MM. Emerging potentials for an antioxidant therapy as a new approach to the treatment of systemic sclerosis. Toxicology 2000; 155:1015.

240. Hascalik S, Celik O, Turkoz Y, Hascalik M, Cigremis Y, Mizrak B, et al. Resveratrol, a red wine constituen polyphenol, protects from ischemia-reperfusion damage of the ovaries. Gynecol Obstetric Invest 2004; 57:218-23.

241. Leonard SS, Xia C, Jiang B-H, Stinefelt B, Klandorf H, Harris $\mathrm{GH}$, et al. Resveratrol scavenges reactive oxygen species and effects radical-induced cellular responses. Biochem Biophys Res Commun 2003; 309:1017-26.

242. Jone KS, Alimov AP, Rilo HL, Jandacek RJ, Woollet LA, Penberthy WT. A high throughput live transparent animal bioassay to identify non-toxic small molecules or genes that regulate vertebrate fat metabolism for obesity drug development. Nutr Metab 2008; 6:23. 
243. Eybl V, Kotyzova D, Koutensky J. Comparative study of natural antioxidants-curcumin, resveratrol and melatonin in cadmium-induced oxidative damage in mice. Toxicology 2006; 225:150-6.

244. Afaq F, Adhami VM, Ahamd N. Prevention of shortterm ultraviolet $\mathrm{B}$ radiation-mediated damages by resveratrol in SKH-1 hairless mice. Toxicol Appl Pharmacol 2003; 186:28-37.

245. Martín AR, Villegas I, La Casa C, de la Lastra CA. Resveratrol, a polyphenol found in grapes, suppresses oxidative damage and stimulates apoptosis during early colonic inflammation in rats. Biochem Pharmacol 2004; 67:1399-410.

246. Lu X, Ji C, Xu H, Li X, Ding H, Ye M, et al. Resveratrol-loaded polymeric micelles protect cells from $A \beta$-induced oxidative stress. Int J Pharmaceut 2009; 375:89-96.

247. Clarke JO, Mullin GE. A review of complemetary and alternative approaches to immunomodulation. Nutr Clin Pract 2008; 23:49-62.

248. Miura T, Muraoka S, Fujimoto Y. Inactivation of creatine kinase induced by stilbene derivatives. Pharmacol Toxicol 2002; 90:66-72.

249. Galati G, Sabzevari O, Wilson JX, O'Brien PJ. Prooxidant activity and cellular effects of the phenoxy radicals of dietary flavonoids and other polyphenolics. Toxicology 2002; 177:91-104.

250. Athar M, Back JH, Kopelovich L, Bickers DR, Kim AL. Multiple molecular targets of resveratrol: anticarcinogenic mechanism. Arch Biochem Biophys 2009; 486:95-1002.

251. Ahmad KA, Clement MV, Pervaiz S. Pro-oxidant activity of low doses of resveratrol inhibits hydrogen peroxide-induced apoptosis. Ann NY Acad Sci 2003; 1010:365-73.

252. Gadacha W, ben-Attia M, Bonnfont-Rousseelot D, Aouani E, Ghanem-Boughanmi N, Touitou Y Resveratrol opposite effects on rat tissue lipid peroxidation: pro-oxidant during day-time and antioxidant at night. Free Radic Res 2009; 14:154-8.

253. Niufar NN, Haycock FL, Wesemann JL, MacStay JA, Heasley VL, Kovacic P. Reduction potentials of conjugated aliphatic ketones, oximes and imines. Rev Soc Quim Mex (J Mex Chem Soc) 2002; 46:307-12.
254. Ames JR, Kovacic P. A mechanism for the toxicity of polychlorinated biphenyls (PCBs), dioxins (TCDD) and dibenzofurans. J Biopharmaceut Sci 1991; 2:32938.

255. Zheng LF, Wei QY, Cai YJ, Fang JG, Zhou B, Yang $\mathrm{L}$, et al. DNA damage induced by resveratrol and its synthetic analogues in the presence of $\mathrm{Cu}(\mathrm{II})$ ions: mechanism and structure-activity relationship. Free Radic Biol Med 2006; 41:1807-16.

256. Azami AS, Bhat SH, Hanif S, Hadi SM. Plant polyphenols mobilize endogenous copper in human peripheral lymphocytes leading to oxidative DNA breakage: a putative mechanism for anticancer properties. FEBS Lett 2006; 580:533-8.

257. Ahamed A, Syed FA, Singh S, Hadi SM. Prooxidan activity of resveratrol in the presence of copper ions: mutagenicity in plasmid DNA. Toxicol Lett 2005; 159:1-12.

258. Azami AS, Bhat SH, Hanif S, Hadi SM. Resveratrol$\mathrm{Cu}(\mathrm{II})$ induced DNA breakage in human peripheral lymphocytes; implications for anticancer properties. FEBS Lett 2005; 579:3131-5.

259. Hadi SM, Asad SF, Singh S, Ahmad A. Putative mechanism for anticancer and apoptosis-inducing properties of plant-derived polyphenolic compounds. IUBMB Life 2000; 50:167-71.

260. de la Lastra CA, Villegas I. Resveratrol as an antioxidant and pro-oxidant agent: mechanisms and clinical implications. Biochem Soc Trans 2007; 35:1156-60.

261. Rüweler M, Gülden M, Maser E, Murias M, Seibert H. Cytotoxic cytoprotective and antioxidant activities of resveratrol and analogues in C6 astroglioma cells in vitro. Chem Biol Interact 2009; 182:128-35.

262. Kovacic P, Somanathan R. Clinical physiology and mechanism of dizocilpine (MK-801): electron transfer radicals, redox metabolites and bioactivity. Oxid Med Cell Longev 2010; 3:13-22.
263. Pristov JB, Spasojevic I, Mikovic Z, Mandic, Cerovic $\mathrm{N}$, Spasic M. Antioxidative defense enzymes in placenta protect placenta and fetus in inherited thrombophilia from hydrogen peroxide. Oxid Med Cell Longev 2009; 2:14-8.

264. Fischer-Wellman K, Bell HK, Bloomer RJ. Oxidative stress and antioxidant defense mechanisms linked to exercise during cardiopulmonary and metabolic disorders. Oxid Med Cell Longev 2009; 2:43-51.

265. Gupta A, Bhatt MLB, Misra MK. Lipid peroxidation and antioxidant status in head and neck squamous cell carcinoma patients. Oxid Med Cell Longev 2009; 2:6672.

266. Bharti VK, Srivatava RS. Pineal proteins upregulate specific antioxidant defense systems in the brain. Oxid Med Cell Longev 2009; 2:88-92.

267. Ozsoy N, Candoken E, Akev N. Implications for degenerative disorders: antioxidative activity, total phenols, flavonoids, ascorbic acid, $\beta$-carotene, $\alpha$-tocopherol in Aloe vera. Oxid Med Cell Longev 2009; 2:98-9.

268. Gomes P, Simão S, Silva E, Pinto V, Amaral JS, Alfonso $\mathrm{J}$, et al. Aging increases oxidative stress and renal expression of oxidant and antioxidant enzymes that are associated with an increased trend in systolic blood pressure. Oxid Med Cell Longev 2009; 2:130-7.

269. Kovacic P, Somanathan R. Novel, unifying mechanism for mescaline in the central nervous system: electrochemistry, catechol redox metabolite, receptor, cell signaling and structure activity relationships. Oxid Med Cell Longev 2009; 2:181-90.

270. Santos IMS, Tomé ADR, Saldanha GB, Ferreira PM, Militão GCG, de Freitas M. Oxidative stress in the hippocampus during experimental seizures can be ameliorated with the antioxidant ascorbic acid. Oxid Med Cell Longev 2009; 2:214-21.

271. Kovacic P, Somanthan R. Zolpidem a clinical hypnotic that affects electronic transfer, alters synaptic activity through potential GABA receptors in the nervous system without significant free radical generation. Oxid Med Cell Longev 2009; 2:52-7. 


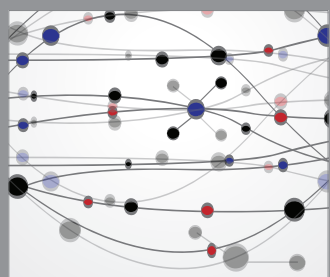

The Scientific World Journal
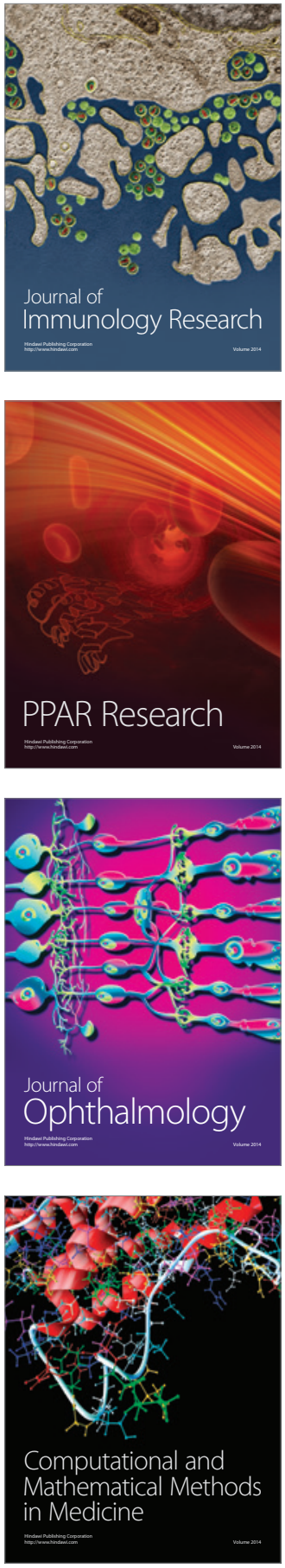

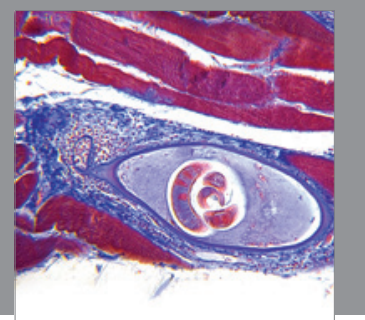

Gastroenterology

Research and Practice
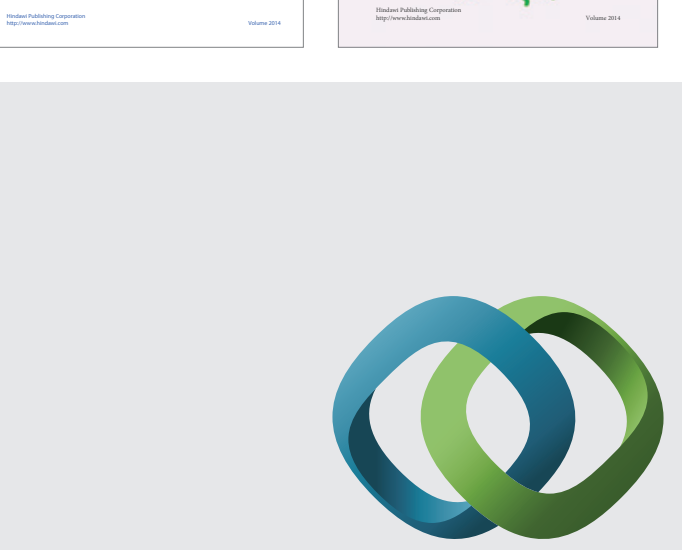

\section{Hindawi}

Submit your manuscripts at

http://www.hindawi.com
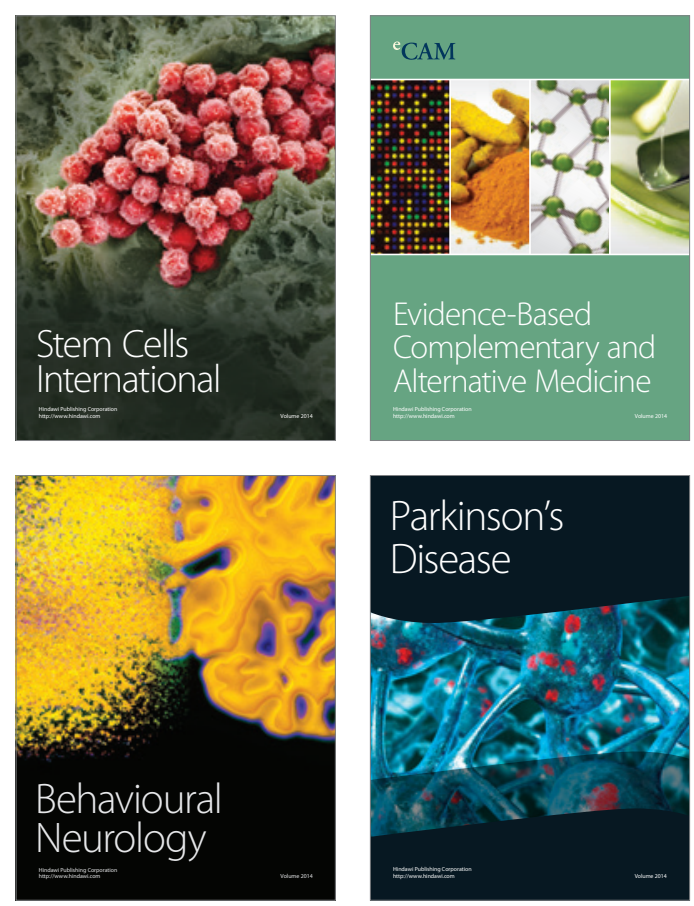

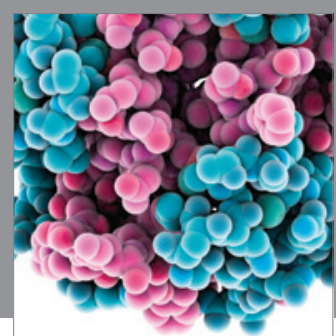

Journal of
Diabetes Research

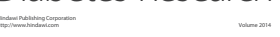

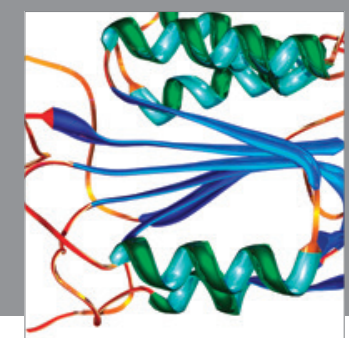

Disease Markers
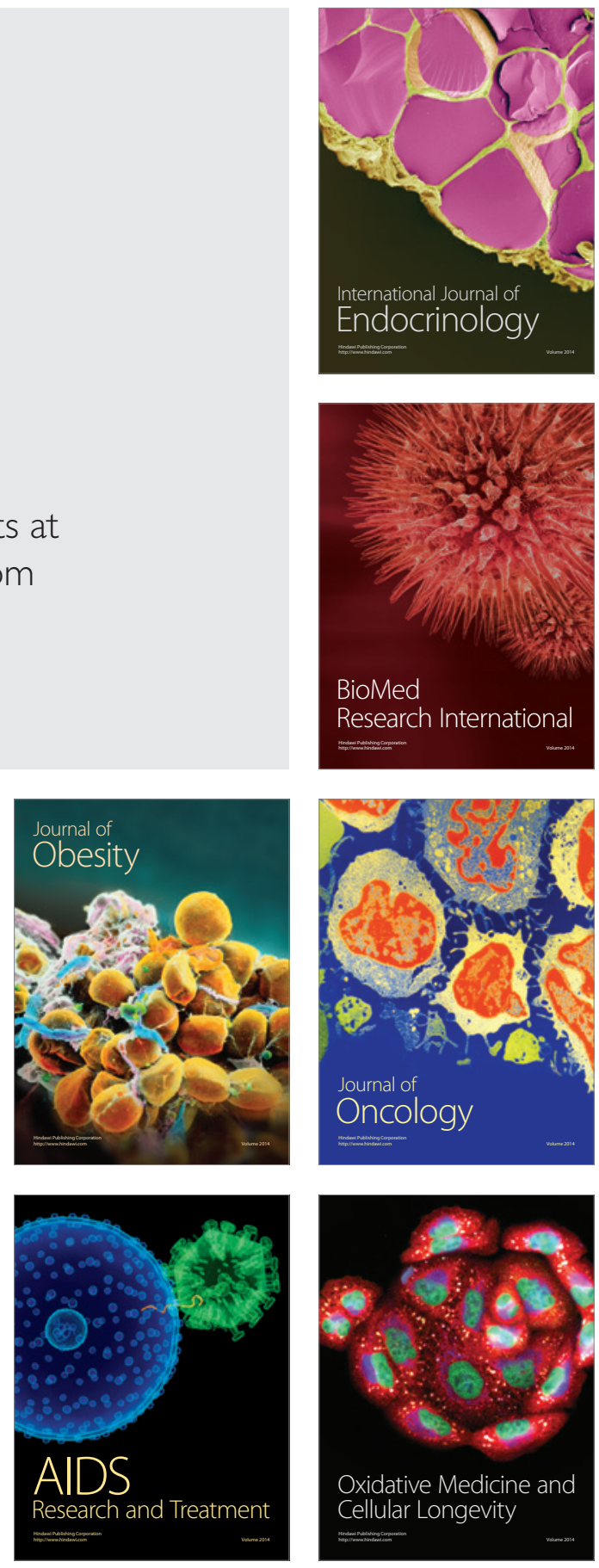